\title{
Sürdürülebilir Mahalle Planlamasının Değişimi, Planlamada Yeni Eğilim “EkoYer” Yaklaşımı ve Türkiye’de Uygulanabilirliği
}

\author{
The Variation of Sustainable Neighborhood Planning, Planning New \\ Trends "Ecodistrict" Approaches and its Application in Turkey
}

\author{
Delda Gülcan Ünal, ${ }^{1}$ (D) Demet Erol ${ }^{2}$ \\ ${ }^{1}$ Gazi Üniversitesi, Fen Bilimleri Enstitüsü, Ankara \\ ${ }^{2}$ Gazi Üniversitesi, Şehir ve Bölge Planlama Bölümü, Ankara
}

\section{ÖZ}

Farklı sosyolojik özellikleri ile mahalleler kent dokusunun en özgün parçasıdır. Aynı zamanda temel bir planlama birimi olarak mahalle her zaman plancıların ve kent vizyonerlerinin özel ilgi alanıdır. Literatürde mahallenin genel bir tanımı olmamakla birlikte mahalle sınırları hem öznel hem de nesnel olarak tanımlanabilmektedir. 20. yüzyılın başlarından beri, daha iyi ve yaşanabilir mahalleler oluşturmak amacıyla çeşitli teoriler ve modeller geliştirilmiştir. Sürdürülebilir kalkınma kavramının ortaya çıkması ile birlikte yer ve yerele vurgu sağlayarak mahalle planlaması için yeni girişimler yükselişe geçmiştir. Mahalle planlaması hareketleri 20. yüzyılın başından, günümüze kadar olan süreçte gelişirken, her planlama hareketi bir önceki yaklaşımdan çıkan derslere göre geliştirilmiştir. Bu makalede de sürdürülebilir mahalle temelli komşuluk birimi planlama hareketleri (tarihsel süreçteki sırası; Bahçe Şehir, Mahalle Birimi, Modernizm, Neo-gelenesel, Eko-kentleşme ve EkoYer hareketleri) ilgili yazındaki eleştirileri ile karşılaştırılarak açıklanmıştır. Yakın zamana rastlayan yaklaşım Ecodistrict olarak literatürde yer almaktadır. Ecodistict kavramının içeriğindeki yer ve yere vurgunun öncelikli olması nedeniyle makalede kavram EkoYer olarak kullanılmıştır. EkoYer hareketinin diğer yaklaşımların sürdürülebilirlik hedefli sentezi, birçok Amerikan ve Avrupa kentinde de uygulama olanağı bulmuştur. Bu nedenle makalenin hedefi Türkiye'deki mahalleleri daha sürdürülebilir ve yaşanabilir kılmak için EkoYer yaklaşımı ile planlamanın mümkün olabileceğidir. EkoYer yaklaşımında kullanılan sosyal, ekonomik, fiziksel bileşenler ile kriterler tanımlanmış, daha sonra Analitik Hiyerarşi Süreci (AHS) yöntemi kullanılarak Türkiye'de yere özgü sürdürülebilir mahalle EkoYer ajanda önerisi geliştirilmiştir. Bu amaçla, mahalle ölçeğinde sürdürebilir insan yerleşimleri tasarımını hedefleyen ve çerçeve niteliğinde içeriğe sahip olan EkoYer hareketinin ülkemizde uygulanabilirliği sonucuna varılmıştır.

Anahtar sözcükler: Analitik Hiyerarşi Süreci (AHS); EkoYer; mahalle ölçeği; sürdürülebilirlik.

\section{ABSTRACT}

Neighborhoods with different sociological characteristics are the most original part of the urban fabric. At the same time, as a basic planning unit, the neighborhood is always of special interest to planners and city visionaries. Although there is no general definition of neighborhood in the literature, neighborhood boundaries can be defined both subjectively and objectively. Since the beginning of the $20^{\text {th }}$ century, various theories and models have been developed to create better and livable neighborhoods. With the emergence of the concept of sustainable development, new initiatives for neighborhood planning have been on the rise with emphasis on place and locality. While the neighborhood planning movements have developed from the beginning of the $20^{\text {th }}$ century to the present day, each process has been selected according to the lessons learned from the previous approach. In this article, sustainable neighborhood based neighborhood unit planning movements (historical order; Garden City, Neighborhood Unit, Modernism, Neo-traditional, Eco-urbanization and Ecodistrict movements) are explained by comparing with their criticisms in the related literature. The most recent approach is the Ecodistrict in the literature. Since the emphasis on the place and place in the content of the Ecodistict concept has priority, the concept has been used as the EkoYer. The sustainability-targeted synthesis of the other approaches of the Ecodistrict movement has also been implemented in many American and European cities. Therefore article's goal, more sustainable neighborhoods in Turkey and that there may be possible with the planning ecodistrict approach to make livable. Ecodistrict approach used in social, economic, physical components defined criteria, then the Analytic Hierarchy Process (AHP) in Turkey, using the method of location-specific sustainable neighborhood ecodistrict the organizer of proposals have been developed. For this purpose, it is concluded that the ecodistrict movement, which aims to design sustainable human settlements at the neighborhood scale and which has a framework content, is applicable in our country.

Keywords: Analytic Hierarchy Process (AHP); ecodistrict; neighborhood scale; sustainability.

Geliş tarihi: 01.08.2019 Kabul tarihi: 18.11.2019

Online yayımlanma tarihi: 17.02.2020

İletişim: Selda Gülcan Ünal.

e-posta: seldagulcanunal@gmail.com 


\section{Giriş}

Sürdürülebilir ve yaşanabilir bir mahalle oluşturmak, yaşam kalitesinin korunması açısından önemlidir. İyi planlanmış bir mahalle, yerel topluluklar arasında bir çeşit sosyal etkileşimi başlatma veya etkileme potansiyeline sahiptir. Birçok planlama yaklaşımı, sosyal etkileşimi ve komşuluk ilişkini geliştiren mahallerden oluşan, yaya dostu caddeleri ve karma kullanımlı kompakt kentsel formu teşvik etmektedir.

Temel bir planlama birimi olan mahalle, plancılar ve kent karar vericileri için her zaman ilgi odağı olmuştur (Rohe,2009). 20 yy. başlarından bu yana, çeşitli teoriler ve modeller daha iyi ve daha yaşanabilir mahalleler yaratmak amacıyla geliştirilmiştir. Yaşanabilir mahalleler sürdürebilirlik refreransına dayanmaktadır. Sürdürülmek istenen ile hem yaşam kültürü hem de mimari biçim detaylandırılmaktadır. Sürdürülebilir kalkınma kavramının çıkışı ve yerel düzeye yaptığı vurgu, mahalle planlaması için yeni girişimler geliştirme yönünde yeni bir ilgi odağı yaratmıştır.

Bu çalışmanın temeli EkoYer yaklaşımı yani Ekolojik Yerleşimlerin ilk hecelerinden oluşmaktadır. EkoYer; insanlar, yeşil binalar ve akıllı altyapı ile sürdürülebilirlik için taahhüt edilen bir mahalledir. EkoYerler, bina ve altyapı projelerini toplum ve bireysel eylemlerle bütünleştirerek mahalle ölçeğinde sürdürülebilir kalkınmayı hızlandırmak için kapsamlı bir strateji geliştirmiştir. Sürdürülebilirliği hızlandıracak önemli bir ölçektir. Hızlı yenilik yapabilecek kadar küçük ve anlamlı bir etkiye sahip olacak kadar büyük bir ölçektir. Kentlerin acilen ihtiyaç duyduğu mahalle tabanlı çözümleri test ve entegre etmek için anlamlı bir yol sunmaktadırlar.

EkoYer; doğal verilerin kullanımına ve akıllı bir sosyal programın uygulanmasına ilişkin ilkeler ve tasarım hedefleri belirlenmesine yardımcı olmaktadır. Mekânları ve çevreyi insanlar arasında ilişki kurmaya dönük olarak ve sürdürülebilir gelişme içinde ele almaktadır. Ekonomik sosyal yaşamı zenginleştiren, renklendiren mekân koşulları yaratılmasında anahtar rol oynamaktadır.

Aynı zamanda EkoYer'ler, kentte yaşayanlar için yaşama zevki veren mekânlar yaratma sanatı olarak da bakılmaktadır. Kültürel sınırları aşan yerel kültür öğelerini tanıyarak, bu kültürü korumak için halkı, katılımcı olarak devreye sokmaktadır.

EkoYer'in kazandırdığı içerik, sadece fiziksel düzenleme ile ilgili değil, diğer alanlarda da görülmektedir. Böylece EkoYer; kimliği güçlendirme, topluluk duygusunu oluşturma amacıyla, kamusal ve özel alanlarda tasarım öğeleri yaratılmasında ve denetlemede kullanılmaktadır. Ayrıca sosyal yararlılık sağlayan ve insanların gereksinimlerini belirleyen çözümler getirmektedir.
Ölçek olarak mahallenin seçilmesinin ana sebebi; sürdürülebilir önlemler en iyi küçük ölçeklerde başarılı olduğu içindir. Komşuluk sadece yeşil altyapı ve sürdürülebilir aktiviteleri içermez, aynı zamanda kültürel ve ekonomik olarak insan ilişkilerini gösterir. Bu yapıda başarı sağlamak için yerin, kültürünü kaybetmeden eski kültürel değerlerle inovatif ve teknolojiyi adapte ederek kentin merkezinde yapılı çevreye yeniden müdahale edilerek karma kullanımlı, enerjisini üreten, suyun dönüşümünü sağlayan, bir atık yönetim politikası olan doğa ve insan dostu yaşam çevreleri tasarlamaktır.

Planlama yaklaşımının evrimine bakıldığında komşuluk ölçeğinde birçok teori ortaya atılmış ve uygulanmıştır (Garden city, Neighborhood unit, Modernism, Eco-urbanism vb). Ancak bu kavramlar üzerinde yeterince uzlaşma olmamış ve son $30 \mathrm{yıl}$ içinde ekoloji ile aynı kavramlara farklı alanlarda kullanımlar geliştirilmiştir. Bu nedenle EkoYer kavramı ile bu anlam karışıklı̆̆ına açıklık getirilmiştir

Çalışmanın amacı, sürdürülebilirlik ilkeleri çerçevesinde, yeni vizyon EkoYer tasarımının hedeflerini saptamak ve bu hedeflere ulaşmak için uygulanabilir bir model/rehber/ajanda hazırlamaktır. Bu nedenle öncelikle mahalle kavramı tartışılmıştır. Mahalle kavramına yüklenen anlamlar literatürde yer alış biçimlerine göre ele alınmış ve mahalle ve ilçe arasında yer alan "district" kavramının içerdiği çok faktörlü içerik tartışılmıştır. District kavramı yerine "yer" kavramının ele alınmasının gerekçeleri anlatılmıştır. Açıklanan sürecin sonunda EkoYer Hareketi (Ecodistrict Movement) gündeme gelmiştir. Daha sonra EkoYer yaklaşımında kullanılan kriterlere değinilmiş ve açıklanan EkoYer kriterleri ile birlikte Analitik Hiyerarşi Süreci (AHS) yöntemi ile Türkiye'de yere özgü sürdürülebilir mahalle EkoYer ajandası oluşturulmuştur. EkoYer ilkelerinin Türk plan kademeleri içinde, karar aktarımı ile uygulanabilir olması kentlerinin sürdürülebilirliği açısında da önemlidir. Bu nedenle EkoYer ajandası plan kademeleri bütününde uygulabilir bir ajandadır.

\section{Mahalle Planlamasının Yükseliş Süreci}

20. yüzyılın başından günümüze kadar mahalle veya küçük ölçekli yerleşimlerin planlaması hareketleri üzerine çok fazla yazın bulunmaktadır. Bu konudaki tüm yazının temeli sürdürülebilir komşuluk gelişimi teorisi ve pratiği üzerinedir. Sürdürülebilir yerleşim planlaması akımlarını inceleyen Wheeler (2004) ve Sharifi (2016) literatürün en önemli dayanağıdır.

- Bahçe Kenti (Garden City),

- Mahalle Birimi (Neighborhood Unit),

- Modernizm (Modernism),

- Neo geleneksel (Neo-Traditional)

- Eko-kentleşme (Eco-Urbanism)

- EkoYer (Ecodistrict) dir. 


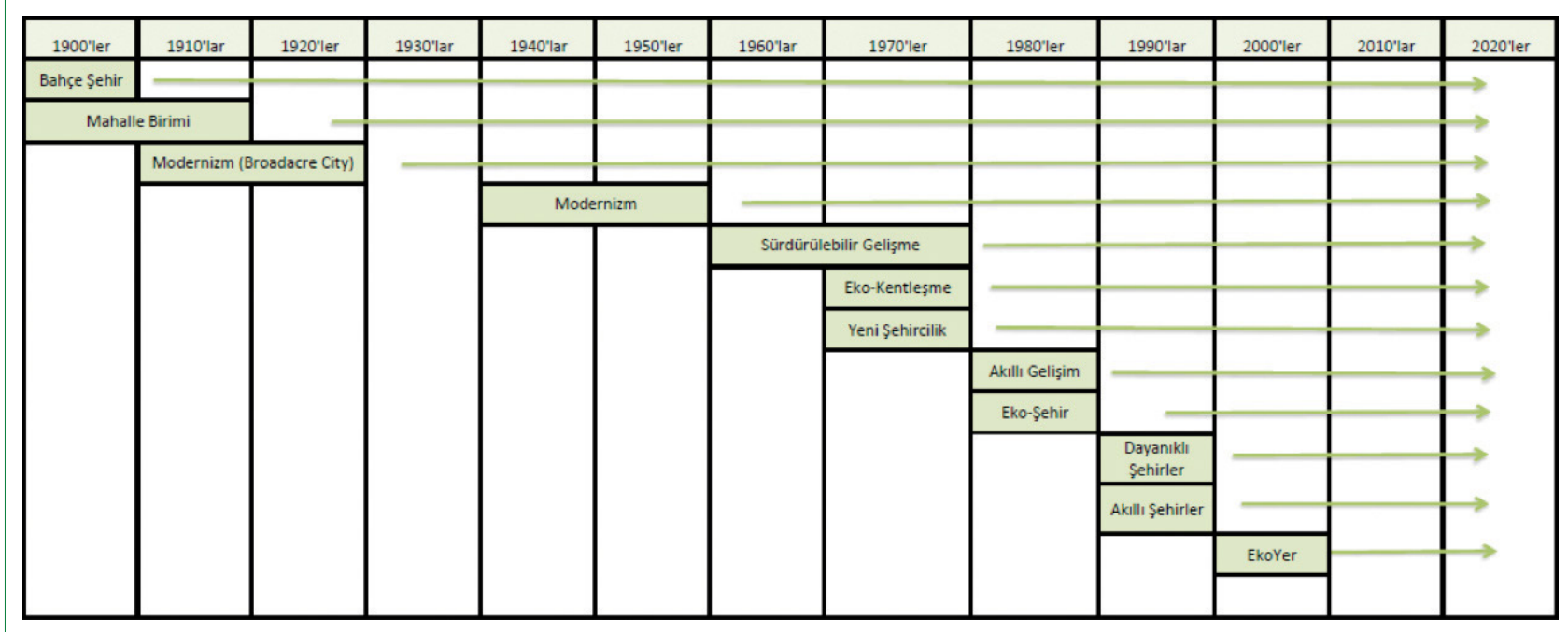

Şekil I. Akımların değişen gündemi ve kilit figürleri (Sharifi, 20।6'dan esinlenilmiş̧ir).

Radyan Şehir, Broadacre Şehri, Geleneksel Mahalle Gelişimi, Transit Yönelimli Gelişim, Yeni Kentleşme, Akıllı Büyüme gibi diğer hareketler; kendi kökeni ve altta yatan ilkelere dayalı, bu altı hareketin alt kümeleri olarak sınıflanmaktadır. Bu hareketler üzerine çok fazla araştırma yapılmasına rağmen, daha önceki çalışmalar genellikle tek bir hareketi açıklamak üzere odaklanmış ve farklı hareketleri araştıran ve karşılaştıran çok az çalışma vardır. Bununla birlikte, çalışma Neo-geleneksel hareketler üzerinde sınırlı bir odak noktasına sahiptir ve ekokentleşme hareketlerini içermemektedir (Şekil I).

Bahçe şehir hareketinden Eko-kentleşme'ye kadar geçen 5 hareketin özelliği ve neden başarı sağlanmadı̆ına yönelik yorum ve eleştiriler bu bölümde açıklanmıştır. Ayrıca tüm bu özelliği anlatılan hareketlerden yola çıkarak EkoYer Hareketi, detaylı özelliklerine ve kriterlerine açıklık getirilmiştir.

\section{I.I. Bahçe Şehir Hareketi (Garden City Movement)}

20. yüzyılın ilk yarısında Ebenezer Howard Bahçe Şehir Hareketini, sosyal kent ilkeleri ile tanımlamaktadır. Kent ve kırın en iyi özelliklerin birleşimi olarak kabul edilen bahçe kent, yeşil bir kuşakla çevrili ve büyük bir ana kentin etrafına yerleştirilmiş birbiriyle ağ bağlantıları olan ve kendine yeten yeni kentlerin bir takımyıldızı olarak tanımlamıştır (Vernet ve Coste 2017; Evalina ve Sawab 20II). Bu döngüsel yeni şehirlerin her biri, orada çalışmakta olan 5000 kişiyi barındıracak şekilde tasarlanmış altı bölüme ayrılmıştır (Howard, 1985; Sharifi, 2016). Howard'un şemasında kasabalar birbirine ve eski şehre demiryolu ile bağlanmış ve büyümeyi kısıtlamak ve tarım ve rekreasyon alanlarını korumak için yeşil bantlarla ayrılmıştır (Sharifi ve Murayama 2013 a, Purdom 1913).

Howard'ın Bahçe Kentini birkaç bölüme ayırma önerisi, mahalle fikrini planlama bağlamına getirmek için yapılan en erken çabalardan biri olarak kabul edilebilir (Johnson, 2002; Minnery, Knight, Byrne ve Spencer, 2009). Her uydu şehri dairesel biçimde olacak ve yaklaşık 400 hektarlık bir alanı kapsayacaktır (Purdom, 1913, Duany, Roberts ve Talen, 2014). Şehir merkezinde yaklaşık 2 hektarlık dairesel bir bahçe olacaktır. "Belediye binası, konferans salonu, tiyatro, kütüphane, müze, resim galerisi ve hastane" gibi diğer tesisler bu şehir merkezini çevreleyecektir (Purdom, 1913 s.120; Basiago, 1996 s.137).

Howard'ın planlı topluluklar hakkındaki vizyonu yaygın bir şekilde uygulanmıştır. Howard; Londra'nın banliyö bölgelerindeki Letchworth ve Welwyn adlı iki pilot bahçe ile kentinin geliştirilmesine katkıda bulunmuştur. Howard'ın Bahçe Şehrinin temel özellikleri, geniş yeşil alan, tek ailelik yerleşim birimleri ve sokak desenleri ile savunucularının önerdiği planlarda tekrarlanmıştır. Bu yönleri ile banliyö yayılımı, hızlı kentsel büyüme, kaynakların fazla kullanımından sorumlu olan banliyö geliştirme modeline (Purdom 1913) hakim olmuştur. Bahçe şehirler banliyölerde spekülatif uygulamalarında önünü açmıştır. Bahçe şehri hareketi, mahalle planlamasının bazı temel ilkelerini ortaya koymada etkili olmuştur. Bununla birlikte, Grant'in (2006) belirttiği gibi, pratikte bu hareketin amaçlarına ulaşmak zor olmuştur ve gelişmeler genellikle pazarın cazibesinden kaynaklanmıştır.

\section{I.2. Mahalle Birimi Hareketi (The Neighborhood Unit Movement)}

Howard'ın 20. yüzyıl başlarında önerdiği yeni yaşam alanları, çeşitli disiplinlerden gelen öğrencileri için ilham kaynağı olmuştur. Yeni yaklaşımlar iki farklı tasarım akımı ile ifade edilmektedir. İlki Clarence Stein ve Henry Wright'ın komşuluk ünitesi yaklaşımları (Radburn ve Sunnyside Gardens planları), ikincisi, Perry'nin mahalle birimi fikridir (Patricios, 2002). 1928 yılında C. Stein tarafından Radburn ilkeleri adıyla geliştirilen komşuluk 
unitesi yaklaşımı araç yollarından tamamen arındırılmış, yaya erişebilir okul, ticari birimler ve eğlence tesislerinin oluşturulduğu merkez ile en uzak konuttan 10 dakika erişme mesafesi ve 800 metre uzaklık esasına dayanmaktadır (Ersoy 20I2).

En alt yerleşim ölçeği komşuluk birimi olan mahalle tasarımı, ilk kez kuram olarak Perry tarafından 1916 yılında geliştirilmiştir. Perry'nin önerdiği komşuluk/mahalle birimi, bir ilkokulun gerektirdiği nüfus esasına dayanmaktadır (Ersoy 20I2). 1923 yılında Clarence Perry, daha önce toplum temelli sosyal aktivitelerden esinlenerek ve Bahçe Kent (Garden City) ve Yerleşim Evi Hareketi (Settlement House Movement) gibi konseptlerden etkilenmiş ve Mahalle Biriminde; yabancılaşma, gençlerde suç oranın artışı gibi sosyal problemleri ele almaya yönelik çalışmıştır. Fiziksel tasarımı güçlendirerek vatandaş katılımı eksikliğini (Brody, 2009; Lawhon, 2009; Rohe, 2009) açıklamıştır. Kentsel planlama ve tasarım tarihinde etkili bir konsept olarak Mahalle Birimi, mahalle planlama hareketlerinin evriminde önemli bir rol oynamıştır (Mehaffy, Porta ve Romice, 2014).

Mahalle Birimi, toplumdaki bazı gruplara karşı ayrımcılığa uğratılabilecek sosyal homojenliği savunduğu için eleştirilmiştir (Gillette, 2010; Lawhon, 2009; Rohe, 2009; Silver, 1985; Talen, 2005). Ayrıca mahalleyi tanımlamak için fiziksel önlemleri esas alan (Mehaffy ve diğerleri, 20।4) fiziki determinizm yaklaşımına sahip olmaktan ve fiziki tasarımı toplumsal reform getirmek için yeterli gören bir şey olduğu için eleştirilmiştir (Gillette, 2010; Silver, 1985). Eleştirmenler Mahalle Biriminin sosyal hedeflerinin fiziksel olanlara dayandığını savunmuşlardır. Buna ek olarak, Bahçe Şehir gibi, Mahalle Birimleri de kendi kendine yetebilen hedeflerine ulaşamamışlardır (Gillette, 20I0).

Bununla birlikte, Mahalle Birimi teorisi daha önceki çabalar üzerine kurulmasında önemli bir rol oynamıştır. Dünyadaki birçok plancı tarafından mahalle tasarımının iyi bir modeli olarak halen kullanılmaktadır (Lawhon, 2009; Mehaffy ve diğerleri, 20|4).

\section{I.3. Modernizm Hareketi (The Modernism Movement)}

İnşaat ve ulaştırma endüstrisinde devrim yaratan teknolojik gelişmelere dayanan rasyonel bir planlama paradigmasıdır. Modernizm ve Bahçe Kent arasında ortaya çıktıkları koşullar ve takip ettikleri hedefler bakımından belirgin bir benzerlik vardır. Burada da, asıl amaç insanoğlu ile doğayı bir araya getirmek ve her ikisi arasındaki simbiyotik ilişkiyi eski haline getirmek ve son derece kalabalık kentsel alanlardaki sosyal adaletsizlik, karışık, sağlıksız ve estetik açıdan hoş olmayan yaşam alanlarının olması gibi yaygın sorunlarla baş etmektir (Basiago, 1996; Fishman, 1977). Bu nedenle, yaygın olan bu sorunlarla baş etmesi açısından planlama ve toplumsal bir hareket olarak görülebilir.
Gerçekte Modernizm, Bahçe Kenti ve Mahalle Birimi hareketlerinde öngörülen kentsel formlardan belirgin olarak farklıdır. Le Corbusier ve Frank Lloyd Wright gibi Modernizmin önemli savunucuları, bu sorunların iyi tasarlanmış bir kent formu ile ele alınabileceğini inanıyorlardı. Modernizm hareketi tarafından teşvik edilen mahalle, yüksek katlı fonksiyonel binalar, büyük açık alanlar, iç yaya yollarına sahip süper bloklar ve modern, yüksek hızlı toplu taşıma biriminden oluşmaktadır (Wheeler, 2004). Bu durum, Bahçe Kenti ve Mahalle Birimi'nde önerilen, insan ölçeğine daha fazla önem verilen mahallelerden, yüksek katlı binalara vurgu yapılmıştır. Alan ve nüfus bakımından kent boyutunda bir sınır mevcuttur.

Modernizm hareketi hem insanlar hem de çevre üzerindeki olumsuz etkileri nedeniyle sürekli bilimsel eleştirilere maruz kalmıştır. Talen (2005) gelişmiş kentçilik ilkelerinin olmadığını ileri sürerek Modernizmi "anti-kentcilik" hareketi olarak sınıflandırmaktadır. Kent tarihçisi Lewis Mumford (Basiago, 1996, s. I43'te belirtilmiştir), Modernizmi; "doğayı, makineyi ve insanın faaliyetlerini ve amaçlarını sentez" etmemesi nedeniyle kınamıştır. Bu başarısızlık doğaya ciddi zararlar vermiştir (Basiago, 1996). Modernizm ayrıca, insan ölçeğini, sivil faaliyetleri ve topluluk çekiciliğini ileri işlevsel ve teknik performansa dayanan uygulamalara tabi tutmak için Jane Jacobs ve Yeni Kentçiler (New Urbanists) gibi aktivistler tarafından eleştirilmiştir (Gillette, 2010; Silver, 2006).

Özellikle mahalle sürdürülebilirliğine yönelik bir dezavantaj; arazi kullanımlarını ayrıştırması, otomobil bağımlılığını önemli ölçüde arttırması ve dolayısıyla çevre ve kent gelişmelerinin yaşanabilirliği üzerinde olumsuz etkilere neden olmasıdır. Bu eksikliklerin üstesinden gelmenin bir yolunu aramak, 1980'lerin başında "Neo-geleneksel Planlama” adı verilen yeni bir hareketi ortaya çıkarmıştır.

\section{I.4. Neo-geleneksel Hareketler (Neo-tradional Movement)}

1980'lerin başında plancılar Neo-gelenekselciliği postmodern kentçilik biçimi olarak geliştirmeye başlamışlardır (Sharifi ve Murayama, 20l3b). Neo-geleneksel planlamayı geliştirme çabaları başta $A B D$ olmak üzere birçok ülkede uygulanmaya başlanmıştır. Duany ve Plater Zyberk ve Calthorpe gibi savunucular; otomobil üstünlüğü ve banliyöleşmenin egemenliğini yok sayarak, geleneksel Amerikan mahallelerini taklit etmeye çalıştıkları, yürünebilir, insan ölçeğinde, kompakt, aktif merkezler ve sınırlar olarak bu hareketi tanımlamışlardır (Basiago, 1996; Gillette, 2010; Nasar, 2003; Silver, 2006).

Son otuz yıl boyunca, Geleneksel Mahalle Geliştirme (GMG), Transit Odaklı Kalkınma (TOK), Yeni Şehircilik ve Akıllı Büyüme gibi farklı isimler Neo-geleneksel ilkelere odaklanan programları tanımlamak için kullanılmıştır (Furuseth, 1997). Yeni Şehircilik, planlama topluluğunda belki de en iyi bilinen isimdir. 
Ortak bir strateji olarak, Neo-gelenekselci yaklaşımların tümü, kentsel ve mahalle sorunlarını çözmeye ve fiziksel tasarım yoluyla toplumsal değişime çözüm aramışlardır. Karma kullanım, farklı konut tipleri, konut- iş yakınlığı, toplu taşıma, en aza indirgenmiş otomobil bağımlılı̆̆ı, insan ölçekli ve cazip sokak manzaraları ve ağaçlarla kaplı sokaklar, yürünebilir çevre, birbirine bağı ve yaya odaklı sokaklar, açık kenarlar, tanımlanabilir kamusal merkezler, yeterli açık alan, estetik ve ayırtedici bir mimari nitelik, kompakt form ve orta yoğunluklu yerleşimler tüm Neo-geleneksel yaklaşımların ortak tasarım ilkeleridir (Beatley ve Brower, 1993; MacLeod, 2013; Nasar, 2003; Talen, 2005; Wheeler, 2004).

Tüm Neo-geleneksel hareketler, temel bir planlama birimi olarak mahalleye yoğun bir şekilde odaklanmaktadır. Neo-geleneksel hareket ve emsalleri birbirini dışlamamaktadır. Modernizme karşı bir tepki olarak, Neo-gelenekselci mahalleye yaklaşımı, yirminci yüzyılın başlarında ortaya çıkan planlama hareketlerine önemli ölçüde benzerlik göstermektedir (Fainstein, 2000). Daha önceki hareketlerde olduğu gibi, Neogeleneksel mahalle, sınırlar ve iyi tanımlanmış bir merkez tarafından tanımlanmaktadır (Fainstein, 2000). Ancak, sabit bir boyuta daha az vurgu yapılmaktadır. Neo-geleneksel komşuluk hareketi bu konuda daha esnektir ve günlük ihtiyaçların karşılanma alanına ve tesislerin yürünebilir mesafelere yerleştirilmesine daha fazla odaklanmaktadır. Mahalleyi kentsel dokudan ayırmak yerine, çeşitli ölçeklerde kesintisiz bir planlama çalışması yürütmektedir.

Sürdürülebilir mahalle gelişimi için uygun modeller olarak övülsede literatürde neo-geleneksel planlama hareketleri çeşitli nedenlerle eleştirilmiştir. Silver (2006), Yeni Kentciliğin önceki kentsel hareketlerin hatalarından bir şeyler öğrenemediğini savunmaktadır. Fainstein (2000) tarafından ortaya atılan bir diğer olumsuz nokta, Yeni Şehircilik'in temel olarak yeşil alanlara uygulandığı ve bu nedenle banliyö yayılımını tersine çevirme ve ekolojik kaygıları ele alma konusunda başarılı olamadığıdır. Eleştirmenler, daha önceki hareketlerin plancıları gibi, neo-gelenekselcilerin de fiziksel forma odaklandıklarını ve kentsel tasarımın tek başına daha iyi topluluklar yaratabileceğine inandıklarını göstermektedir (Fainstein, 2000; Silver, 2006; Sohmer ve Lang, 2000).

\section{I.5. Ekolojik Kentleşme Hareketi (Eco-urbanism Movement)}

Yüzyılın başından bu yana, sürdürülebilirlik ilkelerini mahalle geliştirmeye entegre etmeye çalışan girişimler küresel olarak yaygınlaşmıştır. Bu girişimlerin kaynağı, sürdürülebilirlik konseptinin ortaya çıktığı 1980’lerin başına kadar uzanmaktadır ve Richard Register, kentin biyolojik bölgesinin ekolojik taşıma kapasitesini de dikkate alan eko-şehirler önermiştir (Register,
2006; Tsolakis ve Anthopoulos, 20I5; Yiğitcanlar ve Lee, 20I3). Eko-kentsel girişimler kentsel metabolizma ve sürdürülebilirlik kavramlarına dayanır ve bu nedenle önceki hareketlere kıyasla daha geniş kapsamlıdır (Holden ve Li, 20l4, Tsolakis ve Anthopoulos, 2015). Eko-kentleşme, kapsamlı bir terim olarak, önceki bölümlerde anlatılan geleneksel kentleşme meydan okumasının yanı sıra, iklim değişikliği ve kaynak kısıtlamasının getirdiği zorlukları da ele alan çeşitli hareketleri ifade eder (Joss, Cowley ve Tomozeiu, 2013).

Eko-şehirciliğin önemli bir ayırt edici özelliği, akıllı şebeke, su arıtma sistemleri, katı atık yönetim sistemleri, güneş enerjisi teknolojisi, net-zero enerji binaları, gerçek zamanlı ulaşım bilgileri, e-çalışma vb gibi yeşil ve/veya her yerde bulunan teknolojilerin birleşmesidir (Joss ve Molella, 2013; Yigitcanlar \& Lee, 20I3). Eko-kent hareketlerinin hepsinde karbon söylemi hakimdir. Bu söylem karbonun atmosfere salınması ve kentler üzerindeki olumsuz etkisine karşılık gelmektedir. Düşük karbonlu şehirlere odaklanma 1997 yılında Kyoto Protokolü'nü takiben, şehirlerin enerji tüketimini ve buna bağlı GHG emisyonlarını azaltmada hayati rol oynayacağını kabul ederek daha iyi bir ivme kazanmıştır (Joss, Cowley, ve Tomozeiu, 2013). Eko-kentsel hareketler, az miktarda ekolojik ayak izi ve doğayla uyumlu yaşama ilkelerini yinelemenin yanı sıra, ekonomik sürdürülebilirlik için açık iş planları ve stratejileri olan kendine yeten topluluklar inşa etmeyi vurgulamaktadır. Bu hareket mahalle biriminden çok kentlere hitap ettiği için, uygulama kısmında ölçek konusunda çeşitli zorluklar çıkacağından ve projelerde halk katılımının düşük olmasından dolayı eleştiriler almıştır. Bu eleştirilere cevap veren diğer dört hareketin olumlu ve olumsuz yönlerini bir araya getirerek çözümler üreten EkoYer hareketi ortaya çıkmıştır.

\section{I.6. EkoYer Hareketi (Ecodistrict Movement)}

Kentler arası sürdürülebilirliğe yönelik itici güçlerde yerel, mahalle temelli çabalar ile çapraz ölçekli ilişkilerde konumların daha iyi anlaşılabilmesi için EkoYerler var olmuş ve göze çarpan, uyumlu süreçler ortaya çıkmıştır. EkoYerler, bugün olduğu gibi, "farklı organizasyonlar, seviyeler ya da ölçekler arasında aracı bir rol oynayan ve bilginin birlikte çalışmasını kolaylaştıran" bir "köprü kurucu örgüt" olarak sınıflandırmaktadır (Cash ve ark., 2006). EkoYerler, şehircilik uzmanları, şehir yetkilileri, iktidardaki diğer insanlar ve toplum liderleri, bölge sakinleri arasında köprü oluşturmaktadır. Bilgi paylaşımı ve kaynaklarla bağlantı kurma merkezi olarak EkoYerin, mahalleleri her yerde farklı şekilde anlaması zorunludur. Her mahalleye göre yazılabilecek kendine özgü bir çerçeve bulunmaktadır. Bu çerçeveyi anlamak için, EkoYerlerin çapraz ölçekli ilişki içindeki konumu, mahalleleri kendi mahalleleri için en uygun kaynaklara, bağlantılara ve çözümlere yönlendirmeye yardımcı olan bir tür eğitim merkezi için en uygun kaynaktır. 
EkoYer Hareketi; 1980'lerin ortalarında akademik dünyanın ilgisini çekmiştir. Sürdürülebilir kalkınma savunucuları tarafından şehir vizyonuna modernist bir bakış açısı getirmiştir. Son yıllarda (2008'den günümüze) Avrupa şehirlerinde EkoYer büyüme örneklerine tanıklık etmekteyiz.

Ekoyerler, kar amacı gütmeyen birer kuruluştur ve sürdürülebilirlik hedeflerini ilerletmek için topluluk ölçekli projeler üretmenin bir yolu olarak Portland, Oregon'da 2009 yılında kurulmuştur (The EcoDistricts Protocol, 2014). Toplumsal sürdürülebilirlik, ekolojik farkındalık ve koruma gibi köklü geçmişe sahip ilerici bir şehir olan Portland, bu konsepti kolaylıkla ele almış ve o zamandan beri beş EkoYer tasarlamıştır. Bunlar Lents, Gateway, South Waterfront, Lloyd Bölgesi ve South of Market'dir (Portland State University-POSI, 2015). Portland Sürdürülebilirlik Enstitüsü (POSI), 2012 yılında EcoDistricts olarak yenilenmiştir ve aynı yıl Amerika Birleşik Devletleri ve Kanada'nın metropol şehrilerinde yüksek yoğunluklu, yeni EkoYerler kurmayı amaçlayan Hedef Şehirler kalkınma programını oluşturmuştur (Ecodistricts, 20I4).

EkoYerler genellikle blokların bir araya geldiği şehirlerin küçük bölümleridir. Bu EkoYer parametreleri planlama, kamuya açık oturumlar, tasarım ve uygulama sürecinden sonra yerel yönetişim tarafından belirlenir. Bir ekoyer mahallelerinin çerçevesi veya tarifi, bina karakterini, uygulanabilir altyapıları ve bölgede yaşayan insanları değerlendirerek karar verilir. Bu modelde, finansmanın, risklerin ve çevresel etkilerin etkili bir şekilde yönetilmesi için sürdürülebilirlik stratejileri bir mahalle ölçeğinde yerine getirilmektedir (POSI, 20II) (POSI, 20I5).

EkoYer; kentsel alanda farklı teknik çözümler ve sürdürülebilir eylemlerin çevresel, sosyal, ekonomik etkilerini minimize etmeye çalışmaktadır. EkoYer savunucularının temel amacı; şu an modern şehirciliğin getirdiği sorunların üstesinden gelmektir. Bunu da kentsel sürdürülebilirliği teşvik etme yolunda bir strateji belirleyerek gerçekleştirmektedirler. Literatürde EkoYer birçok farklı sektörün çalışma alanına girmektedir (Seltzer, 20I0) (Smith, 20I3) (Ecodistricts, 20I4). Örneğin; şehir planlama, mimarlık, şehir yönetimi/yönetişim, kentsel politikalar, sürdürülebilir kalkınma gibi.

EkoYer; kentsel dönüşüm için yeni bir model olarak tanımlanmaktadır. Şehrin ve onun mahallelerinin çevresel, ekonomik, sosyal refahını arttırıcı çözümler getirerek kök salmıştır. Geleneksel planlamaya karşı yeni bir yaklaşım getirmektedir (Ecodistricts, 20I4). Böylece şehirleri sürdürülebilir mahalle gelişimine teşvik etmektedir. Kentten izole edilmiş bir mahalleyi değil, kente entegre olan yaşayan, sürdürülebilirliği, dayanıklılığı arttıran, eşitlikçi bir yaşam alanı oluşturmaktadır.

EkoYer konsepti, sürdürülebilir topluluklarda bir model inşa etmek için halk katılımının yazılımı ile (sosyal sermaye, kültü- rel kaynaklar, katılımcı planlama, vb.) yeşil tasarımın donanımıyla (yeşil altyapı, kamusal alanlar, vb.) birleştirerek komşulukların inşa edilmesine yönelik bir çerçeve sunmaktadır. Bu süreç ideal olarak kentler genelinde olay bazında ele alınabilir, böylece kentlerin mahalle düzeyinde sürdürülebilir olmasını (veya daha doğrusu sorumluluğu paylaşma) ve kentin karar verme sürecine daha fazla vatandaş katılımını sağlama çabasını üstlenir (Seltzer, 20I0) (Smith, 2013).

Bir kişinin bir mahalleyi "sürdürülebilir" hale getiren şeyi yorumlaması, diğerlerinden farklı olabilir ve böylece toplulukların yaklaşımlarını kendi özel gereksinimlerine ve önceliklerine uyarlamaları teşvik edilir. Aynı şehirde bulunan çeşitli EkoYerlerin, uygulamaları ve beklenen sonuçları birbirlerinden çok farklı olabilir. Bununla birlikte, çoğunlukla, "yeşil”, "çevre dostu" veya "sürdürülebilir" mahalle ve kent kavramı; bisiklet yolları, üretici pazarları, rüzgar türbinleri ve güneş panelleri, bol yeşil alanlar ve altyapı, "yaşayan” binalar gibi belirli görüntüler akla getirmektedir. "Sürdürülebilir" veya "yeşil” mahalleye ait bu karakteristik yönler, Portland, Oregon'daki Portland Sürdürülebilirlik Enstitüsü (PoSI) tarafından birincil odak noktasına bakılmaksızın (yani kahverengi alan yenilenmesi, sürdürülebilir ekonomik canlanma, vb.) EkoYer tarafından ele alınması gereken sekiz "sürdürülebilirlik performansı hedefi" içine toplanır (POSI, 20I I). Bunlar:

ı. Topluluk kimliği- Aktif ve farklı katılımlı sağlıklı, eşitlikçi ve yaşamsal topluluklar.

2. Eşit Gelişme - Kalkınma

3. Sağlık+ Mutluluk

4. Enerji - Her yıl net sıfır enerji kullanımı.

5. Erişim ve Hareketlilik - Sağıklı, temiz ve uygun fiyatlı ulaşım seçenekleri.

6. Su - Su, her biçimiyle doğal ve insanın ihtiyaçlarını karşılar.

7. Habitat ve Ekosistem İşlevi - Sağlıklı kentsel ekosistemler için yerleşik ve doğal ortamları entegre eder.

8. Materyal Yönetimi - Sıfır atık ve optimize malzeme yönetimi. Bu performans hedeflerini takip ederek, bir mahalle önemli bir hafifletici önlem almaktadır.

Bu performans hedeflerini takip ederek bir mahalle, topluluk kurumlarını güçlendirerek ve kentsel ekoloji ve doğal sistemlere olan vicdani yaklaşımında potansiyel olarak kentsel bir dönüşüm başlatarak (karbon emisyonlarını akıllı geçiş ve enerji kullanımı yoluyla azaltarak) önemli miktarda hafifletici önlemler almaktadır. Bu hedeflerin herbirine ulaşmak için iki yol vardır: PoSI tarafından EkoYer'in "donanım” ve "yazılım” olarak tanımlanan yoludur (Selzter, 2010).

“Donanım”, sürdürülebilir şehirler ve mahalleler düşünüldüğünde çok hızlı bir şekilde akla gelen yağmursuyu yönetimi altyapısı, çeşitli ulaşım seçenekleri, yenilenmiş binalar ve emisyon azaltma hedefleri, iklim olaylarından etkili şekilde korunan güç ve iletişim hatları gibi yapılı çevreyi kapsamaktadır. 
Kısacası, sürdürülebilir mahallelerin en gözle görülür yönü ve niceliksel olarak ölçülebilen politikalarıdır.

Bir EkoYer'in "yazılımı” bir topluluğun niteliksel ya da daha az kolaylıkla tanımlanmış toplumsal güçlüğüdür. Bir mahallenin sosyal esnekliği ve sürdürülebilirlik işaretleri, yerel demokratik süreçlere ve topluluk kaynaklarının yönetimine, birbirine bağlı ve eşitlikçi yerel ekonomi, canlı kültür kurumları ya da mahallenin geleceği ve doğal ve sosyal sistemlerinin sağlığı için ortak bir sorumluluk duygusuna bağlıdır.

"Yazılım” üzerine yoğun önem veren bir bölge veya topluluğun, Tim Smith tarafından tanımlanan "Topluluk Ekolojisi”; coğrafi olarak tanımlanmış bir topluluk ve şehir alanında ortak fayda sağlamak için hareket eden vatandaşlar tarafından öngörülen, oluşturulan ve yönetilen entegre bir enerji, besin, kaynak, finansal, bilgi ve kültürel akışlar ve etkileşimler ağıdır. İnsan ekolojisi, hem doğal hem de sosyal / kültürel sistemleri tamamen birleştiren bir yerdir. Bu "topluluğun bir yazılımı" dır. Topluluk Ekolojinin çerçevesi, yerleşimler için yeni bir paradigmayı, daha verimli bir kentleşmenin ötesine geçen ve derin sürdürülebilirliğe uzanan yumuşak bir kentsel tasarım sistemidir (Smith, 2013).

Topluluk Ekolojisi, sürdürülebilir topluluklar oluşturmak için demokrasiye dayalı, tüm sistemler içeren bir çerçevedir. Çerçeve, her yaştan, kültürden ve vatandaşlarının kendi topluluklarının benzersiz "yazılımlarını" (bütünleşik enerji, besin, su, atık, malzeme ve gıda sistemlerinin yanı sıra ekonomik akışlar ve kültürel etkileşimler) öngörmek, oluşturmak ve yönetmek için yeteneklerini güçlendirmeye odaklanmaktadır. Bu akışları keşfetmek ve desteklemek, toplulukların yerel varlıklarını (çevresel, ekonomik ve sosyal), esnekliklerini ve rekabet edebilirliklerini geliştirmelerini sağlamak ve işbirliği ve inovasyon yoluyla geleceklerini tasarlama ve yönetme kontrollerini almalarına yardımcı olmaktadır. Topluluk Ekolojisi, esnek topluluklar ve yerler yaratmada temel ilk adımdır.

Şu ana kadar iklim değişikliğiyle mücadele için, azaltma ve uyarlama olmak üzere iki strateji tartışılmıştır. Genellikle, her ikisi de kentsel "donanım” ya da yapılı çevre açısından tartışılır (elbette azaltma ve uyarlama için bir "yazılım” yaklaşımı da vardır). Üçüncüsü daha az tartışılan bir strateji, dönüşümler veya kentlerimizin ve toplumlarımızın nasıl işlediğidir (değer sorgulama, varsayımlara meydan okuma ve sabit inançları, kimlikleri ve kalıpları yakından inceleme kapasitesini içeren bir süreçtir). Zor olmasına rağmen dönüşüm hem azaltımı hem de uyarlamayı kapsar ve bizi zorunluluğa zorlamak yerine, almak istediğimiz dönüştürücü yolu çizmemizi sağlar.

İdeal olan donanım ve yazılımın birleşimidir. Yeşil binalar ve yeni nesil sürdürülebilir mahalle altyapısı için bağlam sağlamak üzere

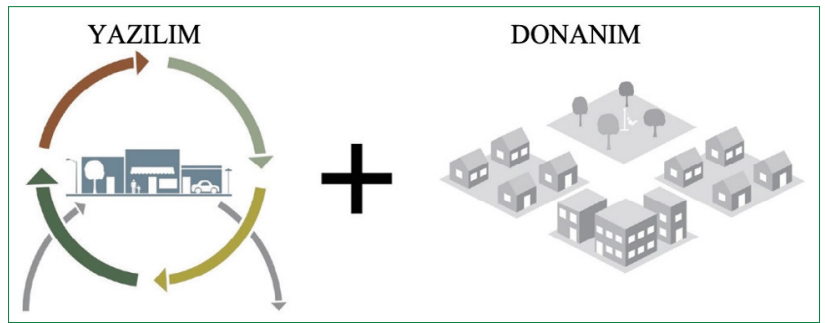

Şekil 2. Basit bir denklem: Yazılım + donanım = sürdürülebilir topluluk= topluluk ekolojisi (Kaynak: Smith, 20I3).

tasarlanan yerel tabanlı kaynak akışlarının kapsamlı bir ağını ortaya çıkaran sağlam sivil katılım ile açık alanları, yeşil caddeleri ve yeşil çatıları yiyecek üretimi, atık yönetimi, enerji üretimi ve su sistemleriyle bütünleştiren “doğa işleri”dir (Şekil 2).

Topluluk Ekolojisi, topluluk yaşamını canlandıran akışların ağıdır. Esnek topluluklar, yaşanabilirliği artıran rafine bir yerel tabanlı sistem dizisine sahip olmaktadır. Buradaki öncül, iyi toplulukların iyi yazılımlara sahip olmasıdır. Dahası, sistemler ve akışlar, sıfır toplamlı olmayan bir oyunda ekonomik, ekolojik ve sosyal ilişkileri birbirine karıştırarak sektörleri çaprazlamaktadır. Dirençli bir toplulukta, ekonomik ve temel sosyal ve ekolojik bileşenlerini içermeyen bir sistem tanımlamak mümkün olmayacaktır.

Mahalle için Toplum Ekolojisi çerçevesi, kentsel dönüşüm için bir mahallenin sürdürülebilirliğe geçiş yolunda vatandaşın daha fazla sahiplenilmesinin yanı sıra vatandaşların mahalle ve şehirle olan ilişkilerini yeniden değerlendirmesini gerektirecek potansiyeli sunar. Sadece bir mahalleyi “yeşilleştirmek" değil, aynı zamanda, gerçek sürdürülebilirlik ve esneklik için kararlı değerler ve demokratik katılım temelinde yaşayan bir toplum yaratmak istenmektedir. Bu çerçevede faaliyet gösteren çeşitli EkoYerlerden oluşan bir şehir, kentleşmiş bir dünyada adil ve sürdürülebilir bir şekilde yaşamak zorunda olduğumuz paradigma değişimini etkili bir ölçekte başlatabilmektedir.

\section{Sürdürebilir Kalkınma ve Ekolojik Yaklaşımlı Mahalle Planlama Deneyimleri Açısından Bir Karşılaştırma}

20. yüzyılın başlarından itibaren mahalle, planlama hareketlerinin dönüşümünün odak noktası olmuştur. Yüz yıldan uzun bir süredir, plancılar ve vizyonerler, düzenlenmemiş kentleşmenin yol açtığı sorunların çözüm yolları olarak planlı mahalleleri geliştirmişlerdir. Bir önceki kısımda Bahçe Şehir, Mahalle Birimi, Modenizm, Neo-geleneksel, Ekolojik Kentleşme, EkoYer olmak üzere altı büyük hareketin analizi yapılmıştır. Tablo I bu farklı hareketlerin temel özelliklerini özetlemektedir. Tablo 2 ise sürdürülebilirlik ile ilgili çeşitli kriterleri içermekte ve seçilen hareketlerin temel prensiplerine entegrasyon derecelerini göstermektedir. 
Tablo I. Altı çevreci/ekolojik duyarlı mahalle hareketinin özellikleri

\begin{tabular}{|c|c|c|c|c|c|c|}
\hline Başlık & Bahçe şehir & Mahalle birimi & Modernizm & $\begin{array}{l}\text { Neo-geleneksel } \\
\text { planlama }\end{array}$ & Eko-kentleşme & EkoYer \\
\hline Coğrafi odak & Avrupa ve $A B D$ & Avrupa ve $A B D$ & Avrupa ve $A B D$ & Avrupa ve $A B D$ & Küresel & $A B D$ ve Avrupa \\
\hline Ana ilham veren durum & Kalabalık şehir & Kalabalık şehir & Kalabalık şehir & Kentsel yayılma & İklim değişikliği & $\begin{array}{l}\text { Kalabalık şehir ve } \\
\text { çevresel faktörler }\end{array}$ \\
\hline Önerilen yoğunluk & Düşük & Düşük & Çok yüksek/çok düşük & Orta & Orta & Orta \\
\hline Sokak tipi & Eğrisel & Radyal/liner & Katı ızgara & Esnek Izgara & Hibrid & Hibrid \\
\hline Sokak iletişimi & Düşük & Düşük & Düşük & Yüksek & Yüksek & Yüksek \\
\hline Ulaşım & Özel & Özel & Özel & Karma & Karma & Karma \\
\hline $\begin{array}{l}\text { Doğa ile bütünleşmeyi } \\
\text { teşvik etmek }\end{array}$ & Evet & Hayır & Hayır & Evet & Evet & Evet \\
\hline Teknolojinin kullanılması & Hayır & Hayır & Hayır & Hayır & Evet & Evet \\
\hline $\begin{array}{l}\text { Karbon ayak izi ve } \\
\text { düşük karbonlu gelişim }\end{array}$ & Hayır & Hayır & Hayır & Hayır & Evet & Evet \\
\hline İklim dayanıklılı̆ıı & Hayır & Hayır & Hayır & Hayır & Evet & Evet \\
\hline $\begin{array}{l}\text { Uluslararası hükümet veya } \\
\text { yarı resmi organların katılımı }\end{array}$ & Hayır & Hayır & Hayır & Hayır & Evet & Evet \\
\hline $\begin{array}{l}\text { Performans doğrulama için } \\
\text { değerlendirme araçları }\end{array}$ & Hayır & Hayır & Hayır & Hayır & Evet & Evet \\
\hline Proje uygulanabilirliliği & Yüksek & Yüksek & Düşük & Yüksek & Düşük & Yüksek \\
\hline Paydaş ilişkisi & Zayıf & Zayıf & Zayıf & Güçlü & Zayıf & Güçlü \\
\hline
\end{tabular}

Sürdürülebilirliği değerlendirmek için çeşitli kriterler literatürde mevcuttur (Wheeler, 2004). Bu çalışma, sürdürülebilirlik değerlendirmesi ile ilgili literatürü ayrıntılı bir şekilde gözden geçirmeyi amaçlamadığından, farklı planlama hareketlerinde sürdürülebilirlik kriterlerinin varlığını araştırmak, bu çalışmanın kapsamı dışındadır. Bunun yerine, sürdürülebilirlik kriterlerinin dahil edilmesi için planlama hareketlerinin evrimsel ilerlemesini incelemek için literatürden (Tablo 2) bazı önemli ölçütler çıkarılmıştır. Olası yanlış anlamaları önlemek için, ilk üç hareket ortaya çıktığında sürdürülebilirlik kavramının henüz geliştirilmediğini belirtmek gerekir. Ancak, daha sonra tartışılacağı gibi, bu hareketlerin gündeminde sürdürülebilirlikle ilgili bazı ölçütler mevcuttur. Tablo 2'de sunulan kriterler beş gruba ayrılmıştır. İlk dört kategori, yukarıda belirtilen dört sürdürülebilirlik boyutuna karşılık gelmektedir.

Seçilen hareketleri karşılaştırmak için Tablo I ve 2 kullanılarak, bu hareketlerin ortaya çıkmasına neden olan koşullar ve izledikleri hedefler açısından bazı ortak noktaları paylaştığı görülebilir. Bölüm I'te tartışıldığı gibi, Bahçe Kenti ve Mahalle Birimi daha sonra ortaya çıkan hareketlerin gelişimi ve evriminde önemli bir rol oynamıştır. Bununla birlikte, yeni hareketler (Yeni-gelenekselleşme ve Eko-kentleşme) geçmiş planlama kültürleri arasındaki sinerjiden kazandırılabilecek potansiyel tamamlayıcı menfaatlerden faydalanarak bu hatadan sakınmayı öğrenmiştir.

Seçilen hareketlerin hedeflere ulaşmada başarılı olup olmadığını görmek ve mahalle planlamasında yüzyılı aşkın süredir yapılan araştırma ve uygulamalar sonucunda varılan nokta sürdürülebilir mahallelerin oluşturulmasıdır. Bu oluşumu da EkoYer hareketi ile sağlamak mümkündür. Çünkü EkoYer diğer 5 hareketin olumlu ve olumsuz yönlerini ele alarak daha yaşanabilir bir yerleşim oluşumunun kriterlerini belirlemiştir.

\section{Ekoyer Ajandası}

Ekoyer ajandası 8 performans alanından oluşmaktadır. Bu performans alanları, bir Ekoyer için kritik performans konularıdır. Bütün Ekoyerler tarafından ele alınması gereken ve sağıklı, yaşanabilir mahalleleri temelde destekleyen birbiriyle bağlantılı konular için bir çerçeve oluşturmaktadırlar. Kentsel alanların karşılaştığı büyük zorlukları kapsamaktadır ve mahalle fırsatlarının bu zorlukları anlamlı bir şekilde çözmesi gerekmektedir. Performans alanları, ekonomik sonuçların önceden kararlar aldığını kabul ederek çevresel ve sosyal sonuçlara ağırlıklı olarak yoğunlaşmaktadır.

\section{I. Eşitlikçi Kalkınma (Gelişim)}

$\mathrm{Bu}$ performans alanı, EkoYer projelerini, geliştirmeleriyle yaşam çevrelerine daha fazla eşitlik ve fırsat getirmek için kullanmayı hedeflemektedir. Bir mahalle çevresel yatırımların ilgili sermaye fırsatları ve yararları ele alınmaktadır. Bu projeler, iş yaratma ve eğitim, yerel yatırım, gelişmiş mahalle canlılığı ve karar vermeye erişim için bir araçtır. EkoYer proje geliştirme, şu anda bir mahallede yaşayan ve çalışan kişilere doğrudan fayda sağlayan eşit ve adil bir şekilde yapılmalıdır. 
Tablo 2. Çalışlan hareketlerde sürdürülebilirlikle ilgili kriterlere dahil olma derecesi

\begin{tabular}{|c|c|c|c|c|c|c|}
\hline & Bahçe şehir & Mahalle birimi & Modernizm & Neo-geleneksel & Eko-kentleşme & EkoYer \\
\hline \multicolumn{7}{|l|}{ Sosyal } \\
\hline Karma nüfus profili & $\checkmark$ & $\checkmark$ & $\checkmark$ & $\checkmark$ & $\sqrt{ }$ & $\sqrt{ }$ \\
\hline İletişim aktiviteleri, kentli mekânları & $\checkmark$ & $\checkmark$ & $x$ & $\checkmark$ & $\checkmark$ & $\checkmark$ \\
\hline Eşitlik & $x$ & $x$ & $x$ & $\checkmark$ & $\checkmark$ & $\checkmark$ \\
\hline \multicolumn{7}{|l|}{ Ekonomik } \\
\hline Ev ve işyerine yakınlık & $\checkmark$ & $\mathrm{x}$ & $x$ & $\sqrt{ }$ & $\checkmark$ & $\checkmark$ \\
\hline Kendi kendi yeterlilik & $\checkmark$ & $\checkmark$ & $x$ & $\checkmark$ & $\checkmark$ & $\checkmark$ \\
\hline Kent Merkezinde yer alma & $\mathrm{x}$ & $\mathrm{x}$ & $\checkmark$ & $\checkmark$ & $\mathrm{x}$ & $\checkmark$ \\
\hline \multicolumn{7}{|l|}{ Çevresel } \\
\hline Yer seçimi & $\mathrm{x}$ & $\mathrm{x}$ & $x$ & $\sqrt{ }$ & $\checkmark$ & $\checkmark$ \\
\hline \multicolumn{7}{|l|}{ Kaynakların yönetimi (temiz ve etkili enerji, } \\
\hline su, meteryal, atık) & $\mathrm{x}$ & $\mathrm{x}$ & $x$ & $\checkmark$ & $\checkmark$ & $\checkmark$ \\
\hline Çevrenin korunması (Ekoloji, biyoçeşitlilik) & $x$ & $x$ & $x$ & $\sqrt{ }$ & $\checkmark$ & $\sqrt{ }$ \\
\hline Yeşil Mekânlar & $\mathrm{x}$ & $\mathrm{x}$ & $x$ & $\sqrt{ }$ & $\checkmark$ & $\checkmark$ \\
\hline Mahalle içinde sürdürlebilir ulaşım & $\checkmark$ & $\checkmark$ & $\checkmark$ & $\sqrt{ }$ & $\checkmark$ & $\checkmark$ \\
\hline Sürdürülebilir bina ve topluluklar & $x$ & $x$ & $x$ & $\sqrt{ }$ & $\sqrt{ }$ & $\sqrt{ }$ \\
\hline İklimsel dayanıklıık (düşük karbon salınımı) & $x$ & $x$ & $x$ & $x$ & $\sqrt{ }$ & $\sqrt{ }$ \\
\hline \multicolumn{7}{|l|}{ Kurumsal } \\
\hline Kamu ve özel işbirliği & $\mathrm{x}$ & $\mathrm{x}$ & $x$ & $\sqrt{ }$ & $\checkmark$ & $\sqrt{ }$ \\
\hline $\begin{array}{l}\text { Sürdürülebilir eğitim (inovasyon, } \\
\text { araştırma, geliştirme) }\end{array}$ & $\mathrm{x}$ & $\mathrm{x}$ & $x$ & $\sqrt{ }$ & $\sqrt{ }$ & $\sqrt{ }$ \\
\hline \multicolumn{7}{|l|}{ Tasarım } \\
\hline Yürünebilirlik & $\mathrm{x}$ & $\checkmark$ & $\mathrm{x}$ & $\checkmark$ & $\checkmark$ & $\checkmark$ \\
\hline Erişilebilirlik & $\checkmark$ & $\sqrt{ }$ & $x$ & $\checkmark$ & $\checkmark$ & $\checkmark$ \\
\hline Kompaklık & $x$ & $\checkmark$ & $\checkmark$ & $\sqrt{ }$ & $\sqrt{ }$ & $\sqrt{ }$ \\
\hline Karma Kullanım & $x$ & $x$ & $x$ & $\sqrt{ }$ & $\checkmark$ & $\checkmark$ \\
\hline Bina yerleşimi & $\mathrm{x}$ & $x$ & $x$ & $\mathrm{x}$ & $\checkmark$ & $\checkmark$ \\
\hline Yeşil altyapı & $x$ & $x$ & $x$ & $x$ & $\sqrt{ }$ & $\sqrt{ }$ \\
\hline Teknolojinin yaşam alanına entegresi & $x$ & $x$ & $x$ & $x$ & $x$ & $\sqrt{ }$ \\
\hline Geleneksel komşuluk yapısı & $x$ & $\sqrt{ }$ & $x$ & $\sqrt{ }$ & $x$ & $\checkmark$ \\
\hline Yapı tasarımı & $\checkmark$ & $\sqrt{ }$ & $x$ & $\sqrt{ }$ & $\checkmark$ & $\checkmark$ \\
\hline Mikro ölçekli yerleşim & $\checkmark$ & $\checkmark$ & $\checkmark$ & $\sqrt{ }$ & $x$ & $\checkmark$ \\
\hline
\end{tabular}

Bu performans alanı, EkoYer projelerinin ve süreçlerinin doğasında olan eşitlik fırsatını tanır. Amacı; Eşitlik ve fırsatı teşvik etmek ve fayda ve yatırım ve geliştirme yüklerinin adil bir şekilde dağıııımasını sağlamaktır.

\subsection{Sağlık + Mutluluk}

Bu performans alanı, Ekoyerde tüm insanların sağlı̆ı̆ı ve refahını arttırmayı amaçlamaktadır. Her şeyden önce yaşanabilir yerlerin yaratılması insanlarla ilgilidir. Sağılıklı mahalleler sağlıklı, mutlu insanlara destek olur. Yürünebilen yaşam alanları, kirlenmemiş doğal ortamlar ve temel hizmetlere ve kolaylıklara erişim yoluyla daha sağlıklı toplumlar ve insan refahı elde ederler. Modern toplumda, birçok sağlık eşitsizliği, temel hizmetlere ve toplum yararlarına eşit olmayan erişimden kaynaklanmaktadır. Bu performans alanı, tüm topluluk üyelerinin refahlarını artırmak ve potansiyellerini tam olarak gerçekleştirmek için fırsatlara erişebilmeleri gerektiğini kabul eder. Temel amaç; insan sağlığını ve toplumun refahını teşvik etmektir.

\subsection{Topluluk Kimliği}

$\mathrm{Bu}$ performans alanı benzersiz mahalle kimliğiyle toplum ve fiziksel yer yaratmayı amaçlamaktadır. EkoYer'i yaratma stratejileri yerin kalitesini ve bir mahallenin kimliğini doğal olarak etkiler. Belirlenmiş topluluk değerleriyle projeleri eşitleme fırsatı bulmaktadırlar. Topluluk Kimliği, sosyal bütünlüğü ve yerleşimi harmanlamaktadır. Bir toplum kimliği oluşturmak için insanlar arasındaki ilişkiler ve kentsel tasarım aynı derecede önemlidir. Bu performans alanı, bir EkoYerin bir mahalleye önemli markalaşma ve poz verme (placemaking) değeri sunma imkânını tanır. Temel amaç; yapılı çevre ve bir toplum kültürü yoluyla kaynaşmış mahalle kimliğini yaratmaktır. 


\subsection{Erişim + Hareketlilik}

Bu performans alanı hareketlilik ihtiyaçlarını çevreye duyarlı bir şekilde karşılamaktadır. Ulaşım temel olarak iş, konut, eğitim, market ve topluluk olanaklarına erişim sağlamakla ilgilidir. Erişim + Hareketlilik, ilgili etkileri (enerji kullanımı, emisyonlar ve maliyet) ile transit geçiş şekillerini (yürüyüş, bisiklet, otobüs veya MAX kullanırken, bir araç havuzunda veya tek başına sürüş) bağlar. Bu performans alanı, temel hizmetlere erişmek için yürünebilirlik ve temiz ulaşımın şart olduğunu kabul etmektedir. Temel amacı; temiz ve uygun fiyatlı ulaşım seçeneklerine erişim sağlamaktır.

\subsection{Enerji}

Bu performans alanı, bir EkoYerdeki karbon emisyonlarını en aza indirgemek için enerji kaynaklarının tüketimini ve üretimini değiştirmek istemektedir. Enerji tüketimiyle ilgili tüm olumsuz etkileri ortadan kaldırırken, tam işlevli bir mahalle için gerekli olan enerji kaynaklarının sağlanabileceğini varsayıyor. Entegre bir mahalle stratejisi aracılığıyla net sıfır enerji elde etmek için koruma ve daha sonra alternatif üretimle başlayan birçok kanıtlanmış strateji bulunmaktadır. Bu performans alanı, insanların enerji kaynaklarını algılama şeklimizi önemli ölçüde değiştirmesi gerektiği anlamına geliyor. Temel amaç; yıllık net sıfır enerji kullanımı elde etmektir.

\subsection{Su}

Bu performans alanı, suyun kentsel alanlarda yeniden tanımlanmasıyla suyu sınırlı bir doğal kaynak olarak değerlendirmeyi amaçlamaktadır. Temel insan yaşamı için ve sağlıklı bir ekosistem için gereklidir. EkoYerde su, yerel havzanın ihtiyaçları kadar temel insan ihtiyaçlarını da karşılamalıdır. Bu amaca ulaşmak, insanlar tarafından tüketilen suyun asgariye indirilmesini ve onu arıtmadan ve çevreye geri bırakmadan önce birkaç kez (yağmur suyu, gri su ve siyah su gibi) tekrar kullanılmasını gerektirir. Ancak bu yaklaşımla, doğal çevremizin sağlığının kritik bir göstergesi olan havza sağlığını koruyacaktır. Bu performans alanı, bir EkoYer'in içilebilir su talebini önemli ölçüde azaltabileceğini kabul eder. Temel amaç; hem insan hem de doğanın ihtiyaçlarını güvenilir ve uygun fiyatlı su yönetimi ile karşılamaktır.

\subsection{Habitat + Ekosistem İşlevi}

Bu performans alanı, habitat ve ekosistem işlevini kentsel bir ortamda optimum performansa döndürmeyi amaçlamaktadır. Doğal ve insani ihtiyaçlar arasında, flora ve faunanın, ayrıca toprağın, havanın veya havzanın sağığını tehlikeye atmayan uygun bir denge olduğunu varsaymaktadır. EkoYerler mevcut mahallelere odaklandığından optimum performansı belirlemek için alanın ekolojisini ve yapılı çevrenin koşullarını anlaması gerekir. Bu performans alanı, işlevsel yaşam alanlarını ve ekosistemleri kentsel alanlarda desteklemenin mümkün olduğunu kabul etmektedir. Temel amaç; Habitat ve ekosistem işlevini koruyan ve yenilenen sağlıklı kentsel ekosistemlere kavuşmaktır.

\subsection{Malzeme Yönetimi}

$\mathrm{Bu}$ performans alanı bir mahalledeki malzeme akışlarının olumsuz etkilerini ortadan kaldırmayı amaçlamaktadır. Çoğu malzeme türünün ömrü boyunca insan ve çevre sağlığına zararı vardır. Hedef, her fırsatta malzeme tüketimini azaltmak ve ürünlerin mahalle içine girip çıkma şeklini değiştirmek ve mümkün olduğunca her malzemeden çok fazla değer yakalamaktır. Bu, EkoYer'e girecek ve bu bölgeden çıkacak geniş bir ürün yelpazesine sahip çok sayıda kimyasaldan dolayı özellikle zorlayıcı bir alandır. Bu performans alanı, "atık" tanımını yeniden düşünme ve daha kısıtlı malzeme akışları yaratma fırsatlarının bulunduğunu kabul eder. Temel amaç; sıfır atık ve optimize malzeme yönetimidir.

\section{AHS Yöntemi ile Mahalle Ölçeğinde Türkiye'ye Özgü EkoYer Ajandasının Oluşturulması}

Analitik Hiyerarşi Süreci (AHS), sonlu sayıda seçeneğin ve hem nitel hem de nicel ölçütlerin yer aldığı karar problemlerinde, seçeneklerin değerlendirilmesi için kullanılan çok ölçütlü bir karar verme tekniğidir. AHS, 1980 yılında Thomas Saaty tarafından ilk olarak tanımlanmış, kriterlere ve alt kriterlere dayanan karmaşık kararların alınmasında kullanılmak üzere modellenmiştir. Yöntem, ayrıştırma, karşılaştırmalı değerlendirme ve önceliklerin sentezi dahil olmak üzere üç aşamadan oluşur. Ayrıştırma aşaması; kararın, sorunun temel unsurlarını yakalayan bir hiyerarşiye bölünmesini gerektirir. Karşılaştırmalı değerlendirme aşaması, belirli bir hiyerarşi seviyesindeki öğelerin bir sonraki en yüksek seviyedeki üst düğümü bakımından ikili karşılaştırmaları yoluyla önem ağırlıklarının değerlendirilmesini gerektirir. Sentez aşaması, her karar alternatifi için genel bir öncelik sıralaması yaratır. AHS yöntemini kullanmanın en büyük avantajı uzmanların verdiği sonuçlar arasında tutarlılı̆ı sağlamaktır (Saaty, 1980).

Son zamanlarda, sayısız yazar sürdürülebilirliğin AHP optimizasyon sürecine dahil edilmesi üzerine çalışmıştır (Lee ve Chan, 2008; Bottero, 2015; Gutierrez, 2015; Girard, Cerreta ve De Toro, 2012; Ligmann-Zielinska, Church \& \& Jankowski, 2008; Gonzalez ve diğerleri, 20 I 3; Schadler ve diğerleri, 20 I 3; Kurka, 20I3; Chen ve Lin, 20I I; Lofti, Habibi ve Koohsari, 2009; Poveda ve Lipsett, 20I3; Uribe ve diğerleri, 2014).

Çalışmanın bu kısmı AHS'yi sürdürülebilir mahalleler için Türkiye'ye özgü EkoYer ajandasını oluşturmak üzere benimsemiştir. Veri toplamadan önce karar problemi için hiyerarşik bir karar modeli geliştirmek gerekmektedir. Şekil 3'te gösterilen 


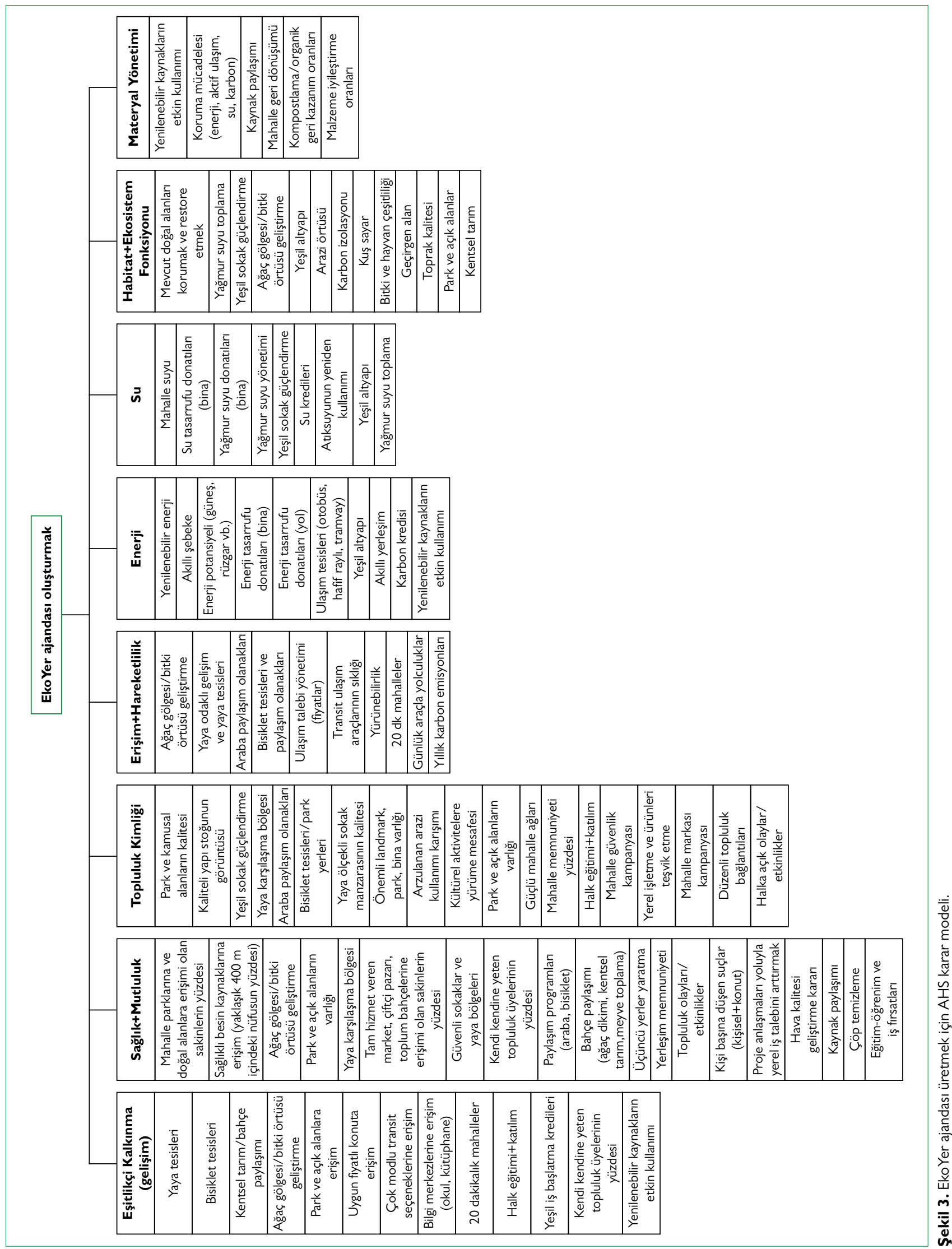


Tablo 3. AHS'deki ikili karşılaştırmalar için 9 puanlık ölçek

\begin{tabular}{lcc}
\hline Önem derecesi & Tanım & Açıklama \\
\hline I & Eşit derecede önemli & İki faktör aynı derecede önem taşımaktadır \\
3 & Orta derecede önemli & İki faktörden biri diğerine göre biraz daha fazla önem taşımaktadır \\
5 & Kuvvetli derecede önemli & İki faktörden biri diğerine göre oldukça önem taşımaktadır \\
7 & Çok kuvvetli derecede önemli & İki faktörden biri diğerine göre çok daha fazla önem taşımaktadır \\
9 & Kesinlikle daha önemli & İki faktörden biri diğerine göre kesinlikle daha önemlidir \\
$2,4,6,8$ & Ara değerler & Tercih değeri birbirine çok yakın olduğunda kullanılır \\
\hline
\end{tabular}

Kaynak: Saaty, 1980.

bu çalışmanın karar modeli, amaç seviyesi, hedef seviyesi ve tasarım kriterleri seviyesi olmak üzere üç ana seviyeye ayrılmıştır. Amaç seviyesi, karar problemini tanımlayan en üst seviyedir. Bu çalışma, sürdürülebilir bir mahallede EkoYer ajandası önerisini ortaya koymaya çalışmaktadır ve bu nedenle, en üst seviye "en iyi teklifi" oluşturmaktır. İkinci seviye, sekiz boyuttan oluşan hedefler düzeyidir. Üçüncü seviye ise çeşitli tasarım kriterlerinden oluşmaktadır. İkinci aşamada sekiz EkoYer kriterinin önceliklerini ve üçüncü düzeydeki farklı tasarım ölçütlerinin göreceli önemini belirlemek için uzmanlar tarafından bir dizi ikili karşılaştırma yapılması gerekmektedir. Her iki seviyedeki unsurlar daha sonra ağırlıklandırılarak her bir potansiyel yenileme teklifi için nihai puan, karar verme sürecine katılan bir grup uzmanın bileşik görüşüne dayanmaktadır. Makale kapsamında ele alınan karar verme süreci, alternatif kararların değerlendirilmesini içermemekte olup yaklaşım kategori ve kriterlerin birbirlerine göre göreceli önem derecelerinin belirlenmesi şeklindedir.

Örnek bir sonuç elde etmek için değerlendirme sürecine uzmanlığı sürdürülebilir yerleşimler olan 30 uzman 2019 yılının ilk 3 ayında çalışmalar için davet edilmiştir. 10'ar kişilik 3 gruba ayrılarak I. grupta şehir plancıları; 2. grupta mimarlar; 3. grupta ise inşaat mühendisleri, peyzaj mimarları, harita mühendisleri vb. oluşmuştur. AHS yürütülürken, tüm uzmanların, Tablo 3'te gösterildiği gibi, 9 puanlık bir ölçeğe dayanarak matrislerdeki farklı kriterlerin göreceli puanları hakkında karar vermeleri istenmiştir.

Görüşme sırasında, her bir uzmandan, Export Choice adlı bir bilgisayar yazılımı yardımıyla AHS değerlendirme sürecinde yer alması istenmektedir. Bu yazılımı kullanarak, hedeflerin ve karşılık gelen kriterlerin göreceli ağırlıkları ve matrislerin tutarlılık oranları (C.R.) hesaplanabilmektedir. Kabul edilemez bir C.R. değeri, yani (0.10) olan herhangi bir matris varsa, o matris üzerinde tekrar karar vermek için uzmana ihtiyaç vardır. Derecelendirme notundaki tutarlılığı arttırmak için uzmanlara ikili karşılaştırma kavramı hakkında bilgi verilmiştir. Örneğin; EkoYer ajandası oluşturmak için uzmanlara Eşitlikçi Kalkınma mı yoksa Sağlık+Mutluluk kriteri mi daha önemli diye sorulduğunda Eşitlikçe Kalkınma 3 puan alıyorsa, diğer kritere göre 3 kat daha önemlidir. Yapılan çalışmada tüm matrislerin C.R. değerleri 0.I0'dan düşüktür ve tutarsızlığa rastlanmadığı için tüm karşılaştırmalar kabul edilmektedir.

Her üç gruptaki bireysel uzmanlardan alınan kararları ayrı ayrı sentezledikten sonra, EkoYer kriterlerinin nihai ağırıklarını ve değerlendirme modelinin geliştirilmesi için tasarım kriterlerini sergilemek için bu sonuçları birleştirmenin uygun olup olmadığına karar vermek gerekmektedir. Cevabı bulmak için Kendall'ın W'nin üretilmesi önerilmiştir. Kendall'ın W'i, sayıların/nesnelerin sayıları için üç veya daha fazla sıra grubu arasındaki anlaşmanın derecesini değerlendirmek için faydalıdır (Sheskin 2003). W'nin olası değeri 0 ile + I arasındadır. Bu W'nin değeri sıfırdır, yani, bu sıra kümesi arasında bir anlaşma kalıbı yoktur, bunun tersi de geçerlidir. 30 uzman kararından her birinin ürettiği bireysel tasarım kriterlerinin öncelikli ağırlıklarını dönüştürmek, Kendall'ın W'ini hesaplamak için bir önkoşuldur.

Normalize ölçümlerde en yüksek değeri I rakamı oluşturmaktadır. Anket sonuçları uzmanlıklara göre karşılaştırıldığında, üç meslek grubunu için öncelikli en yüksek değere sahip kategoriler farklılaşmaktadır. Şehir Plancıları ve Mimarlara göre Eşitlikçi Kalkınma iken İnşaat Mühendisleri, Peyzaj Mimarları ve Harita Mühendislerine göre ise Topluluk Kimliğine en yüksek öncelik verilmiştir. Yine ikincil ve üçüncül kategori olan Topluluk Kimliği ve Sağıı+Mutluluk Şehir Plancıları ve Mimarlarda aynıdır. Bu durum diğer gruptaki uzmanlarda ise Erişim+Hareketlilik ve Materyal Yönetimi şeklindedir (Tablo 4).

Kategori ağırlıkları karşılaştırmalı Şekil 4 incelendiğinde değerlerdeki farklıııklara rağmen, Şehir Plancıları ve Mimarların görüşleri paralel yöndedir. Tüm meslek grupları için sekiz kategoriden beşi yaklaşık olarak eşit derecede öneme sahiptir. Bunlar; Erişim+Hareketlilik, Enerji, Su, Habitat+Ekosistem, Materyal Yönetimidir. Bu durum gösteriyor ki Türkiye'de sürdürülebilir yerleşimler ve mahalleler için olmazsa olmaz kriterleri oluşturmaktadır. Bu kriterler Türkiye'deki mesleki yaklaşımların bütünleştirilmesi ölçüsünde önemli bir fırsat sunmaktadır. 
Tablo 4. Uzmanlıklara göre kategori ağırlık dağılımları

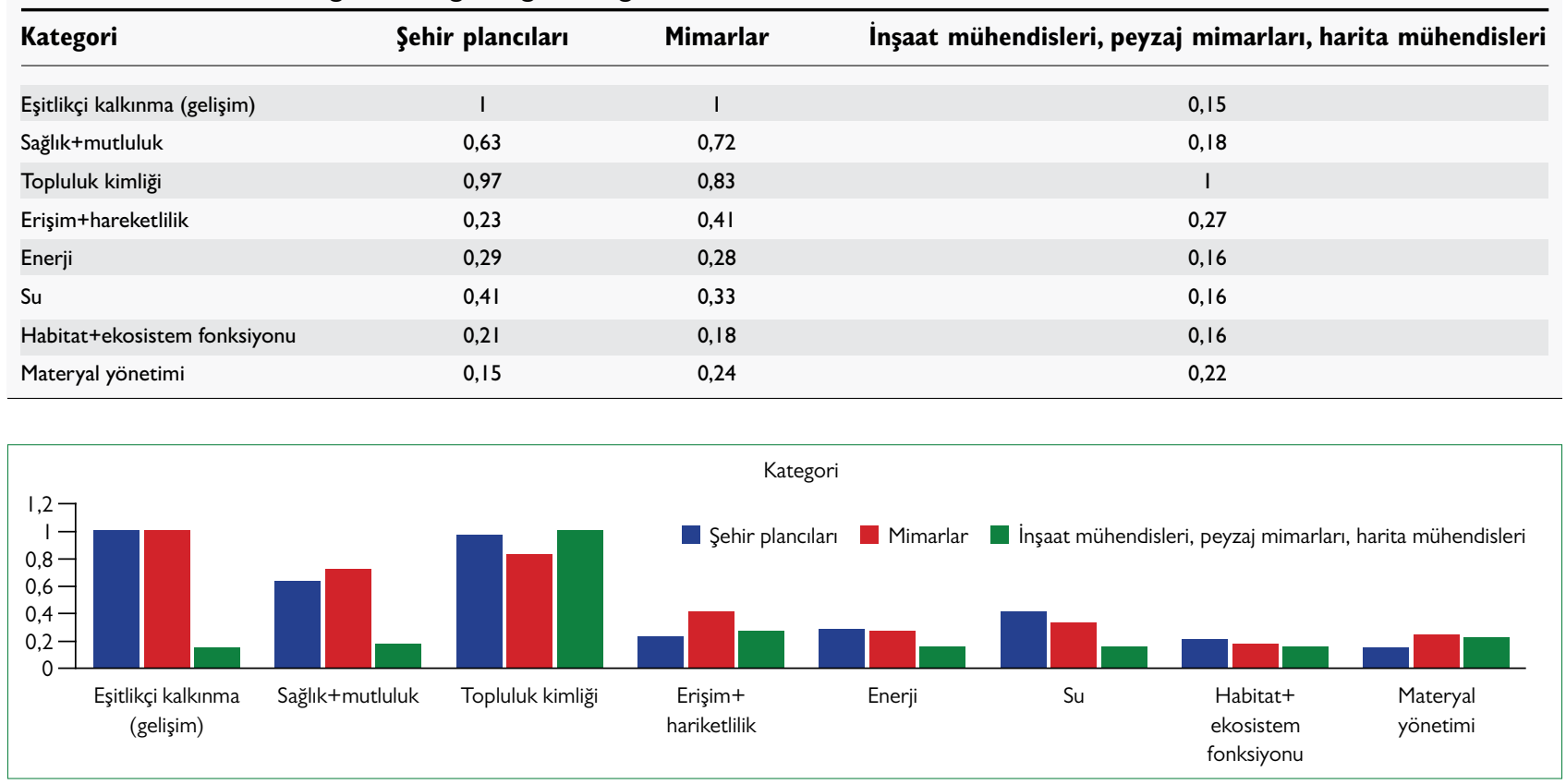

Şekil 4. Uzmanlıklara göre kategori ağılık dağıımlarının karşısaştırııması.

Eşitlikçi Kalkınma kategorisi Şehir Plancıları ve Mimarlar için birinci derece önemliyken diğer uzmanlıklar için sonda yer almaktadır. Topluluk kimliği EkoYer'i yaratmada, yerin kalitesini ve bir mahallenin kimliğini doğal olarak etkilediğinden tüm uzmanlar için vazgeçilmez bir öneme sahiptir. Bu nedenle 30 uzmanda en yüksek puanlamaları bu kategoriye vermiştir.

Eşitlikçi Kalkınma, Sağlık+Mutluluk, Toplum Kimliği yerleşimlerdeki insan faktörünü birincil sıraya koyduğundan birbirleriyle ile yüksek girdi içindedir. Şehir plancıları ve Mimarlar benzer düşünce içinde olduğundan bu üç kategoriyi birbirine yakın değerler vererek ilk üçe yerleştirmişlerdir. İnşaat Müh., Peyzaj Mimarları, Harita Mühendisleri Topluluk Kimliği dışındaki tüm kategorileri birbirine yakın değerler vermişlerdir. Böylece kategorilerin tüm meslek grupları içinde yakın değerler alması tutarlılı̆ın bir göstergesidir. Ayrıca Türkiye'de EkoYer politikalarına duyulan acil ihtiyacı yansıtmaktadır.

Tüm meslek gruplarının bir arada değerlendirilmesi ile ulaşılan sonuçlar her bir kategori ve kriter için son ağırlıkları vermektedir. Anketin uygulanmasında uzmanlardan öncelikle kategorileri başlıklarının daha sonra ise bu başııklar altında yer alan kriterlerin göreceli önemlerini değerlendirmeleri istenmiştir.

Meslek gruplarına göre tüm uzmanlar "topluluk kimliğine" yüksek öncelikle değerlendirildiğinden birinci sırada yer almaktadır. "Eşitlikçi kalkınma" kategorisi 2 uzmanlıktan en yüksek bir uzmanlıktan en düşük değer almasına rağmen grafikte ikinci sırada yer bulmuştur. Diğer sıralamalar ise şu şekildedir:

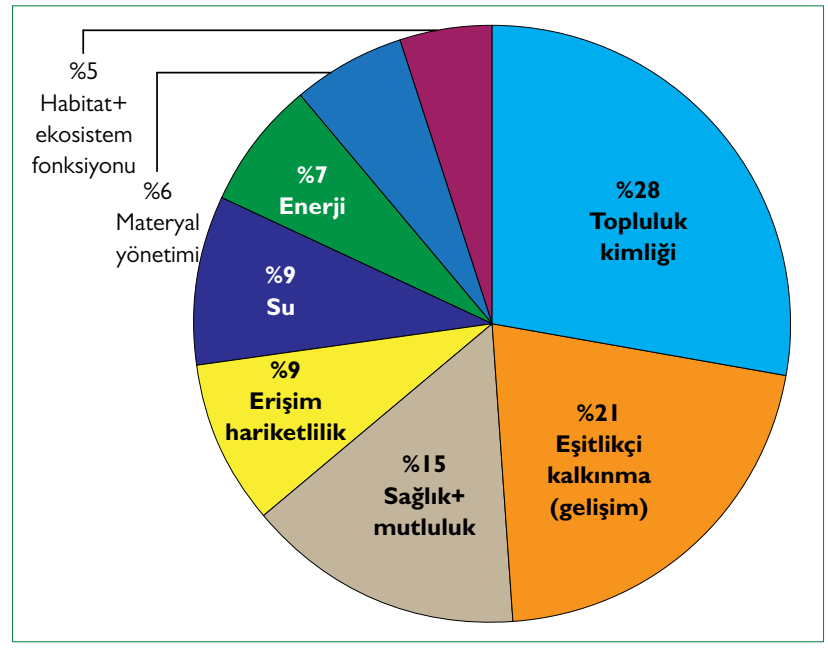

Şekil 5. Tüm uzmanlıklara göre ağılık dağıımı (\%).

sağlık+ mutluluk, erişim+hareketlilik, su, enerji, materyal yönetimi, habitat+ekositem fonksiyonudur (Şekil 5).

Kriterler ilgili göstergeler değerlendirmeyi olanaklı kılan kategorilerdeki en önemli birleşenleri oluşturmaktadır. Bu sebeple ikili karşılaştırmadaki ağırlıkların yerele özgü olması mevcut sistemlerin adaptasyonunda vazgeçilmez bir unsurdur. İkinci aşamada katılımcılardan her bir kriteri kendi kategorisi içinde göreceli önemlerine göre puanlamaları istenmiştir. Aynı kategori başlıkları altındaki kriterlerin birbirine göre önemlerinin belirlenmesi, yaygın bir yaklaşım olmasından dolayı anlaşılabilirlik ve tutarlılık sağlaması açısından tercih edilmiştir (Tablo 5). 
Tablo 5. Kategori ve kriter ağırlıkları

\begin{tabular}{|c|c|c|c|}
\hline Kategori & Ağırlık & Kriter & Ağırlık \\
\hline \multirow[t]{19}{*}{ Topluluk kimliği } & \multirow[t]{19}{*}{1} & Arzulanan arazi kullanımı karışımı & 1 \\
\hline & & Önemli landmark, park, bina varlığı & 0,95 \\
\hline & & Kültürel aktivitelere yürüme mesafesi & 0,89 \\
\hline & & Park ve açık alanların varlığı & 0,84 \\
\hline & & Kaliteli yapı stoğunun görüntüsü & 0,75 \\
\hline & & Yaya karşılaşma bölgesi & 0,72 \\
\hline & & Güçlü mahalle ağları & 0,71 \\
\hline & & Yaya ölçekli sokak manzarasının kalitesi & 0,69 \\
\hline & & Park ve kamusal alanların kalitesi & 0,69 \\
\hline & & Yeşil sokak güçlendirme & 0,66 \\
\hline & & Mahalle memnuniyeti yüzdesi & 0,54 \\
\hline & & Mahalle markası kampanyası & 0,48 \\
\hline & & Düzenli topluluk bağlantıları & 0,46 \\
\hline & & Halka açık olaylar/etkinlikler & 0,46 \\
\hline & & Bisiklet tesisleri/park yerleri & 0,42 \\
\hline & & Mahalle güvenlik kampanyası & $0,4 I$ \\
\hline & & Yerel işletme ve ürünleri teşvik etme & $0,4 I$ \\
\hline & & Halk eğitimi+ katılım & 0,41 \\
\hline & & Araba paylaşım olanakları & 0,39 \\
\hline \multirow[t]{13}{*}{ Eşitlikçi kalkınma (gelişim) } & \multirow[t]{13}{*}{0,78} & 20 dakikalık mahalleler & 1 \\
\hline & & Kendi kendine yeten topluluk üyelerinin yüzdesi & 0,96 \\
\hline & & Yenilenebilir kaynakların etkin kullanımı & 0,75 \\
\hline & & Bilgi merkezlerine erişim (okul, kütüphane) & 0,44 \\
\hline & & Uygun fiyatlı konuta erişim & 0,42 \\
\hline & & Çok modlu transit seçeneklerine erişim & 0,38 \\
\hline & & Park ve açık alanlara erişim & 0,31 \\
\hline & & Halk eğitimi+ katılım & 0,29 \\
\hline & & Yaya tesisleri & 0,24 \\
\hline & & Yeşil iş başlatma kredileri & 0,19 \\
\hline & & Ağaç gölgesi/bitki örtüsü geliştirme & 0,18 \\
\hline & & Kentsel tarım/bahçe paylaşımı & 0,17 \\
\hline & & $\begin{array}{c}\text { Bisiklet tesisleri } \\
\end{array}$ & 0,1 \\
\hline \multirow[t]{19}{*}{ Sağlık+mutluluk } & \multirow[t]{19}{*}{0,57} & Kendi kendine yeten topluluk üyelerinin yüzdesi & 1 \\
\hline & & Yerleşim memnuniyeti & 0,88 \\
\hline & & Üçüncü yerler yaratma & 0,61 \\
\hline & & Topluluk olayları/etkinlikler & 0,58 \\
\hline & & Kaynak paylaşımı & 0,56 \\
\hline & & Sağlıklı besin kaynaklarına erişim (yaklaşık 400 m içindeki nüfusun yüzdesi) & 0,55 \\
\hline & & Tam hizmet veren market, çiftçi pazarı, toplum bahçelerine erişimi olan sakinlerin yüzdesi & 0,48 \\
\hline & & Hava kalitesi geliştirme kararı & 0,47 \\
\hline & & Güvenli sokaklar ve yaya bölgeleri & 0,4 \\
\hline & & Kişi başına düşen suçlar (kişisel+konut) & 0,39 \\
\hline & & Mahalle parklarına ve doğal alanlara erişimi olan sakinlerin yüzdesi & 0,36 \\
\hline & & Bahçe paylaşımı (ağaç dikimi, kentsel tarım, meyve toplama) & 0,35 \\
\hline & & Park ve açık alanların varlığı & 0,33 \\
\hline & & Paylaşım programları (araba, bisiklet) & 0,3 \\
\hline & & Yaya karşılaşma bölgesi & 0,28 \\
\hline & & Ağaç gölgesi/bitki örtüsü geliştirme & 0,26 \\
\hline & & Çöp temizleme & 0,24 \\
\hline & & Eğitim-öğrenim ve iş fırsatları & 0,22 \\
\hline & & Proje anlaşmaları yoluyla yerel iş talebini arttırmak & 0,19 \\
\hline
\end{tabular}


Tablo 5 (devamı). Kategori ve kriter ağırlıkları

\begin{tabular}{|c|c|c|c|}
\hline Kategori & Ağırlık & Kriter & Ağırlık \\
\hline \multirow[t]{10}{*}{ Erişim+hareketlilik } & 0,37 & $20 \mathrm{dk}$ mahalleler & 1 \\
\hline & & Yürünebilirlik & 0,64 \\
\hline & & Yaya odaklı gelişim ve yaya tesisleri & 0,54 \\
\hline & & Transit ulaşım araçlarının sıklığı & 0,42 \\
\hline & & Ulaşım talebi yönetimi (fiyatlar) & 0,4 \\
\hline & & Yıllık karbon emisyonları & 0,39 \\
\hline & & Bisiklet tesisleri ve paylaşım olanakları & 0,32 \\
\hline & & Ağaç gölgesi/bitki örtüsü geliştirme & 0,31 \\
\hline & & Günlük araçla yolculuklar & 0,27 \\
\hline & & Araba paylaşım olanakları & 0,26 \\
\hline \multirow[t]{9}{*}{ Su } & 0,36 & Yeşil altyapı & 1 \\
\hline & & Atıksuyunun yeniden kullanımı & 0,85 \\
\hline & & Yeşil sokak güçlendirme & 0,85 \\
\hline & & Yağmur suyu toplama & 0,84 \\
\hline & & Yağmur suyu yönetimi & 0,58 \\
\hline & & Su tasarrufu donatıları (bina) & 0,53 \\
\hline & & Yağmur suyu donatıları (bina) & 0,53 \\
\hline & & Mahalle suyu & 0,43 \\
\hline & & Su kredileri & 0,34 \\
\hline \multirow[t]{10}{*}{ Enerji } & 0,31 & Akıllı yerleşim & 1 \\
\hline & & Yenilenebilir kaynakların etkin kullanımı & 0,85 \\
\hline & & Yeşil altyapı & 0,52 \\
\hline & & Enerji potansiyeli (güneş, rüzgar vb.) & 0,43 \\
\hline & & Ulaşım tesisleri (otobüs, hafif raylı, tramvay) & 0,32 \\
\hline & & Akıllı şebeke & 0,31 \\
\hline & & Yenilenebilir enerji & 0,3 \\
\hline & & Enerji tasarrufu donatıları (bina) & 0,27 \\
\hline & & Enerji tasarrufu donatıları (yol) & 0,25 \\
\hline & & Karbon kredisi & 0,16 \\
\hline \multirow[t]{6}{*}{ Materyal yönetimi } & 0,27 & Kaynak paylaşımı & 1 \\
\hline & & Yenilenebilir kaynakların etkin kullanımı & 0,82 \\
\hline & & Mahalle geri dönüşümü & 0,69 \\
\hline & & Kompostlama/organik geri kazanım oranları & 0,69 \\
\hline & & Koruma mücadelesi (enerji, aktif ulaşım, su, karbon) & 0,44 \\
\hline & & Malzeme iyileştirme oranları & 0,32 \\
\hline \multirow{13}{*}{$\begin{array}{l}\text { Habitat+ekosistem } \\
\text { fonksiyonu }\end{array}$} & 0,25 & Mevcut doğal alanları korumak ve restore etmek & 1 \\
\hline & & Yeşil altyapı & 0,96 \\
\hline & & Geçirgen alan & 0,9 \\
\hline & & Toprak kalitesi & 0,9 \\
\hline & & Arazi örtüsü & 0,86 \\
\hline & & Bitki ve hayvan çeşitliliği & 0,84 \\
\hline & & Park ve açık alanlar & 0,81 \\
\hline & & Yeşil sokak güçlendirme & 0,76 \\
\hline & & Ağaç gölgesi/bitki örtüsü geliştirme & 0,75 \\
\hline & & Kentsel tarım & 0,74 \\
\hline & & Kuş sayar & 0,56 \\
\hline & & Yağmur suyu toplama & 0,43 \\
\hline & & Karbon izolasyonu & 0,43 \\
\hline
\end{tabular}

Kriterlerin değerlendirilmesi sonucunda ortaya çıkan toplam ağılıklara göre Eşitlikçi Kalkınma kategorisi altında 13 kriter değerlendirilmeye alınmıştır. Buna göre en yüksek önceliği
"20 dakikalık mahalleler" ve "kendi kendine yeten topluluk üyelerinin yüzdesi” kriterleri \% 18 ile birinci sırayı paylaşmışlardır. Bunları \%।4 ile "yenilenebilir kaynakların etkin kullanı- 


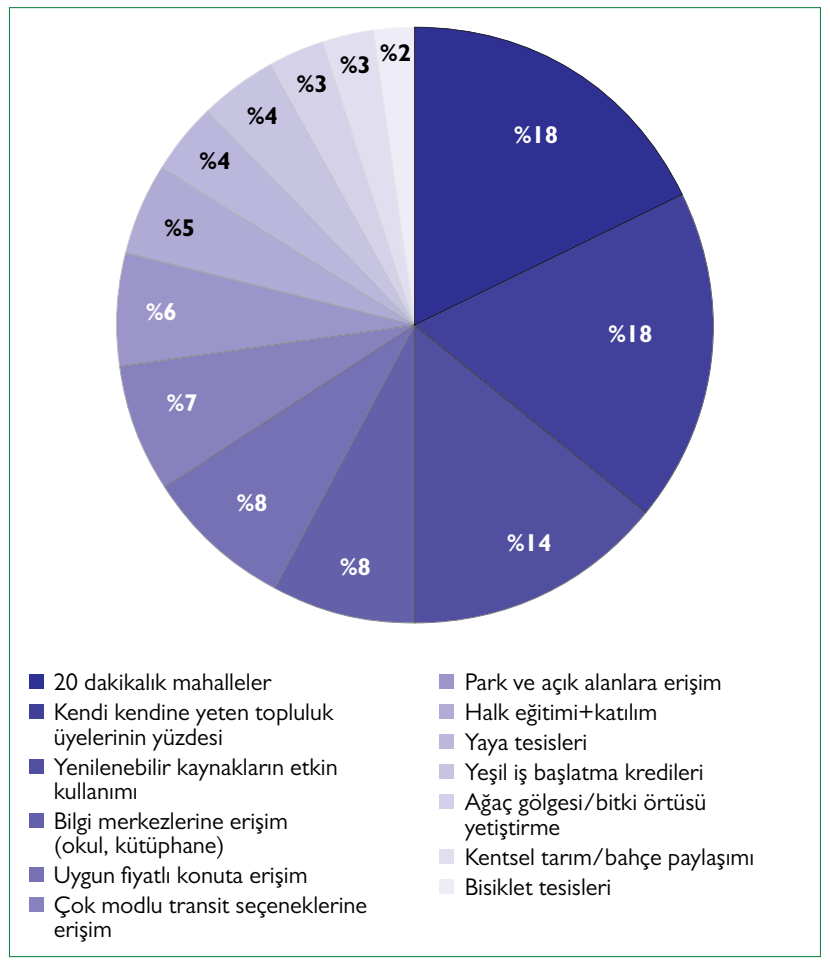

Şekil 6. Eşitlikçi kalkınma kriter ağıılıkları (\%).

mı" ikincil sırada; "bilgi merkezlerine erişim" ve "uygun fiyatlı konuta erişim" ise \%8 ile üçüncül sırada eşit öneme sahiptir. Sıralamaya devam ettiğimizde \%7 ile "çok modlu transit seçeneklerine erişim"; "park ve açık alanlara erişim" \%6; "halk eğitimi+katılım" \%5; "yaya tesisleri" ve "yeşil iş başlatma kredileri" \%4; "ağaç gölgesi/bitki örtüsü geliştirme" ve "kentsel tarım/bahçe paylaşımı" \%3; "bisiklet tesisleri" \%2 değere sahiptir (Şekil 6).

Sağlık ve mutluluk kategorisinin 19 kriteri bulunmaktadır. Önceliklere göre "kendi kendine yeten topluluk üyelerinin yüzdesi" ve "yerleşim memnuniyeti" en öncelikli iki kriter olarak değerlendirilmiştir. Illk iki kriterden sonraki tüm kriterler birbirine yakın ağırlıklar alarak eş ağırlıklara sahip olmuşlardır. Sıralamaya devam ettiğimizde; "üçüncü yerler yaratma", "topluluk olayları", "kaynak paylaşımı" ve "sağılılı besin kaynaklarına erişim" eşit ağılıkları paylaşmaktadır. Bunları "tam hizmet veren market, çiftçi pazarı, toplum bahçelerine erişimi olan sakinlerin yüzdesi”, "hava kalitesi geliştirme kararı", "güvenli sokaklar ve yaya bölgeleri”, "kişi başına düşen suçlar", "mahalle parklarına ve doğal alanlara erişimi olan sakinlerin yüzdesi", "bahçe paylaşımı”, "park ve açık alanların varlı̆ı̆”, "paylaşım programları”, "yaya karşılaşma bölgesi”, "ağaç gölgesi/bitki örtüsü geliştirme", "çöp temizleme", "eğitim -öğrenim ve iş firsatları", "proje anlaşmaları yoluyla yerel iş talebini arttırmak" izlemektedir (Şekil 7).

Topluluk Kimliği EkoYer ajandasının 8 kategorisinden birisini oluşturmaktadır. Bu kategoride belirlenen öncelikler Türkiye

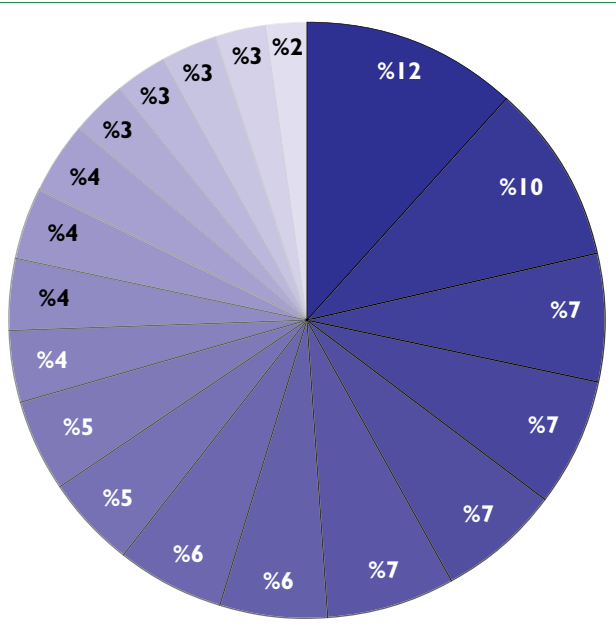

Kendi kendine yeten topluluk üyelerinin yüzdesi

- Yerleşim memnuniyeti

- Üçüncü yerler yaratma

- Topluluk olayları/etkinlikler

- Kaynak paylaşımı

- Sağlıklı besin kaynaklarına erişim (yaklaşık 400 m içindeki nüfusun yüzdesi)

- Tam hizmet veren market, çiftçi pazarı toplum bahçelerine erişim olan sakinlerin yüzdesi

- Hava kalitesi geliştirme kararı

- Güvenli sokaklar ve yaya bölgeleri
- Kişi başınna düşen suçlar (kişisel+konut)

- Mahalle parklarına ve doğal alanlara erişimi olan sakinlerin yüzdesi

- Bahçe paylaşımı (ağaç dikimi, kentsel tarım, meyve toplama)

- Park ve açık alanların varlığı

- Paylaşım programları (araba, bisiklet)

- Yaya karşılaşma bölgesi

Ağaç gölgesi/bitki örtüsü geliştirme

- Çöp temizleme

Eğitim-öğrenim ve iş fırsatları

Proje anlaşmaları yoluyla yerel iş talebini artırmak
Şekil 7. Sağlık+mutluluk kriter ağırlıkları (\%).

özgü bir ajanda oluşturması sürecinde en önemli katagoridir. Bu kategori altında yer alan 19 kriter ile Sağlık+Mutluluk kategorisi ile birlikte en çok kriter içeren kategoridir. Bu kriterlerin göreceli önemine göre sıralanmasında en yüksek (\%8) öncelik "arzulanan arazi kullanımı karışımı” ve "önemli landmark, park, bina varlığı” kriterlerine verilmiştir. Bu sırayı \%7 ağırlık oranı ile "kültürel aktivitelere yürüme mesafesi" ve "park ve açık alanların varlığı” izlemiştir. \%6 ağırlık oranı ile 6 kriter üçüncü derece önem sırasındadır. Bu kriterler; "kaliteli yapı stoğunun görüntüsü”, “yaya karşılaşma bölgesi”, "güçlü mahalle ağları”, "yaya ölçekli sokak manzarasının kalitesi”, "park ve kamusal alanların kalitesi”, "yeşil sokak güçlendirme”dir. "Mahalle memnuniyeti yüzdesi” \%5 ağırlığa sahiptir. \%4 ile "mahalle markası kampanyası”, “düzenli topluluk bağlantıları”, "halka açık olaylar/etkinlikler", "bisiklet tesisleri/park yerleri” kriterleri eşit orana sahiptir. Son sırada ise \%3 ile "mahalle güvenlik kampanyası", "yerel işletme ve ürünleri teşvik etme”, "halk eğitimi+ katılım” ve " araba paylaşım olanakları” gelmektedir (Şekil 8).

Erişim+Hareketlilik kategorisi 10 kriter içermektedir. "20 dakikalık mahalleler” \%22 oranı ile en yüksek ağırlığa sahip kriter olmuştur. Bunu \% I4 ile "yürünebilirlik" ve \% I 2 ile "yaya odakli gelişim ve yaya tesisleri” izlemektedir. Diğer kriterlerin ağırlık dağılımları incelendiğinde \%9 ile "transit ulaşım araçlarının sık- 


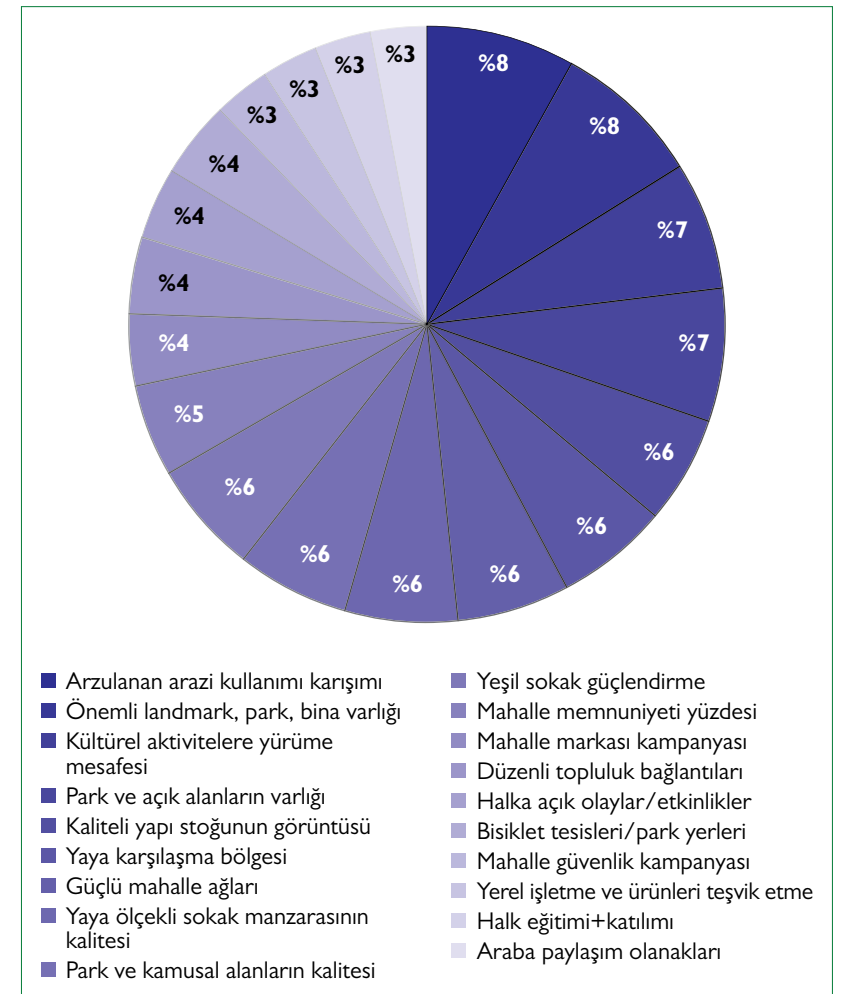

Şekil 8. Topluluk kimliği kriter ağılıkları (\%)

lığı" ve "ulaşım talebi yönetimi (fiyatlar)"; \%8 ile "yıllık karbon emisyonları"; \%7 ile "bisiklet tesisleri ve paylaşım olanakları" ve "ağaç gölgesi/bitki örtüsü geliştirme"; \%6 ile "günlük araçla yolculuklar" ve "araba paylaşım olanakları"dır (Şekil 9).

Enerji kategorisi 10 kriter içermektedir. Bu kategori ile Erişim+Hraketlilik kategorisi benzer ağırlıkları içermektedir. \%23 ağılık oranı ile "akıllı yerleşimler" birinci sırada yer almaktadır. Bu sıralamayı ikinci sırada \% 19 ile "yenilenebilir kaynakların etkin kullanımı" izlemektedir. Diğer kriter ağırlıkları ise şöyledir: \% 2 "yeşil altyapı"; \% I0 "enerji potansiyeli (güneş, rüzgar vb.)"; \%7 ile "ulaşım tesisleri(otobüs, hafif raylı, tramvay)", "akıllı şebeke", "yenilenebilir enerji”; \%6 "enerji tasarrufu donatıları (bina)" ve "enerji tasarrufu donatıları (yol)"; \%3 “karbon kredisi”dir (Şekil I0).

Su kategorisinde 9 kriter yer almaktadır. \%।4 oranı ile "yeşil altyapı" en öncelikli kriter olarak değerlendirilmiştir. Bunu çok yakın bir değer olan \%।4 ile "atık suyunun yeniden kullanımı", yeşil sokak güçlendirme" ve "yağmur suyu toplama" kriterleri izlenmiştir. \% 10 ile "yağmur suyu yönetimi" 3 . derece önem sıralamasında yer almıştır. "Su tasarrufu donatıları (bina)" ve "yağmur suyu donatıları (bina)" \%9 ağırlığa sahiptir. diğer kriterler \%7 ile "mahalle suyu" ve \%6 ile "su kredileri"dir (Şekil II).

Habitat+Ekosistem Fonksiyonu 13 kriterden oluşan bir başka kategoridir. Şekil 12 incelendiğinde bu kategorideki tüm kri-

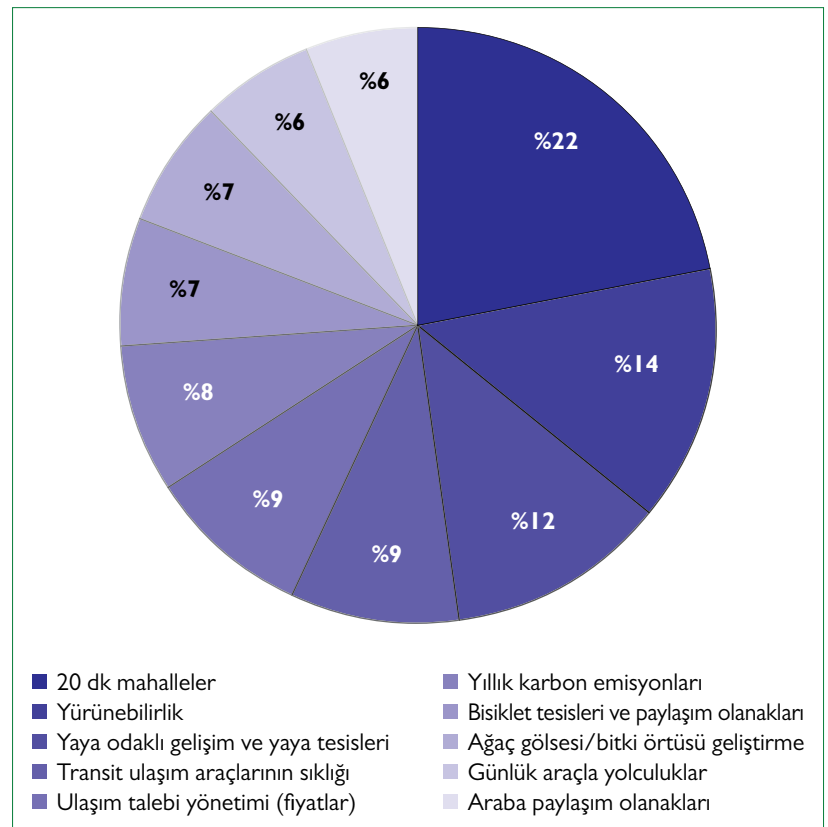

Şekil 9. Erişim+hareketlilik kriter ağılıkları (\%).

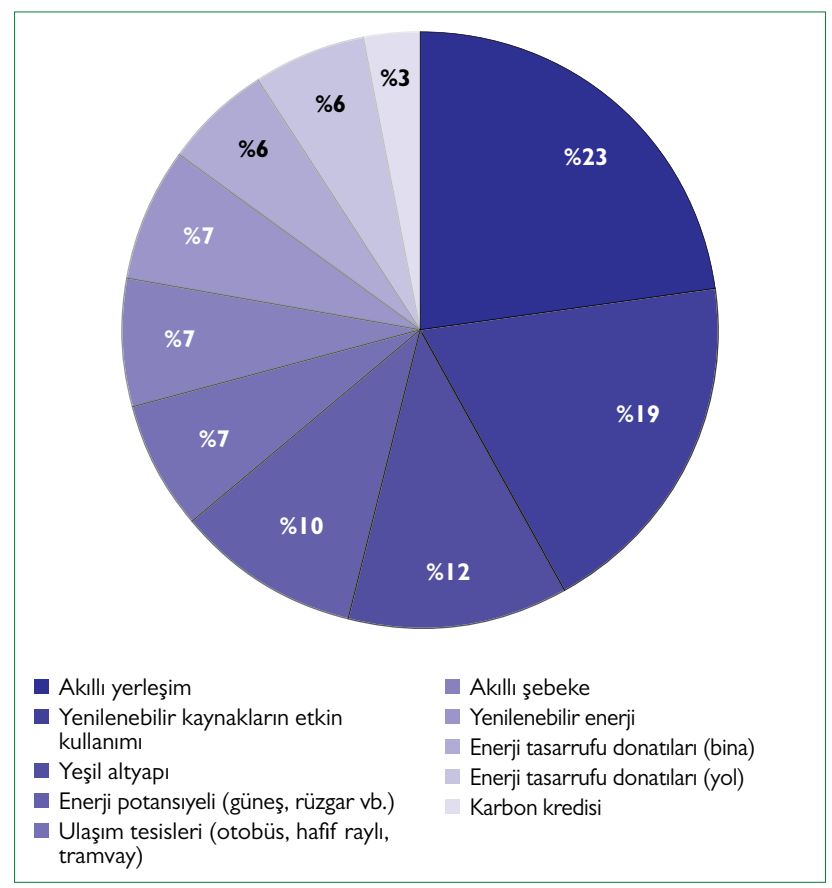

Şekil I0. Enerji kriter ağırıkları (\%).

terlerin pasta dilimleri bir birine çok yakın ağırlıklar almıştır. Bu durum önem derecelerini birbirine yakın göstermektedir. "Mevcut doğal alanları korumak ve restore etmek" ve "yeşil altyapı" \% 10 ile ilk sırayı eşit olarak paylaşmışlardır. İkinci sırayı eşit olarak \%9 oranı ile "geçirgen alan", "toprak kalitesi” ve "arazi örtüsü” almıştır. Üçüncü sırayı \%8 ile "bitki ve hayvan çeşitliliği”, "park ve açık alanlar", "yeşil sokak güçlendirme" ve "ağaç gölgesi/bitki örtüsü geliştirme” paylaşmıştır. Diğer kri- 


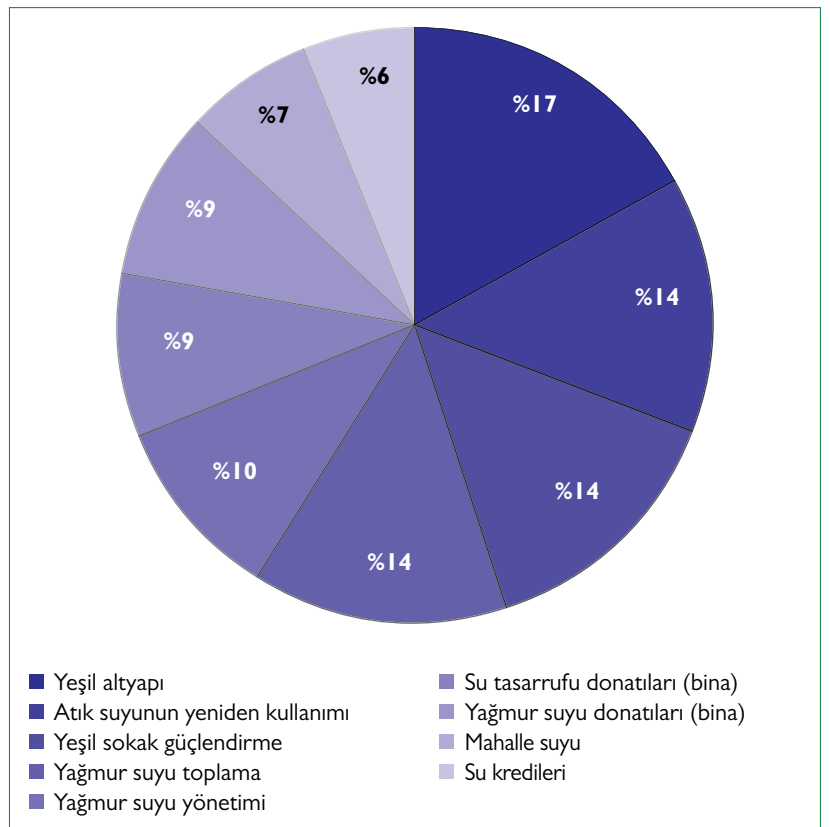

Şekil I I. Su kriter ağılııkları (\%).

terler ise şöyledir: \%7 ile "kentsel tarım"; \%6 ile "kuş sayar", \%4 ile "yağmur suyu toplama" ve "karbon izolasyonu"dur.

Son kategori olan Materyal Yönetimi en az kritere sahip tek kategoridir. 6 kriterin ilkini \%25 ağrılığa sahip "kaynak paylaşımıdır" oluşturmaktadır. \%2I ve \% I8 ile ikinci ve üçüncü sırayı "yenilenebilir kaynakların etkin kullanımı" ve "mahalle geri dönüşümü" oluşturmaktadır. Bu sırayı \%17 ile "kompostlama/organik geri kazanım oranları", \% II ile "koruma mücadelesi" ve \%8 ile "malzeme iyileştirme oranları" takip etmektedir (Şekil I3).

Kategori ve kriter ağılıkları üç farklı uzmanlıkdaki karar vericilerin bütünleşik kararlarını özetlemektedir (Tablo 5). Tablo ağılıklara göre sıralanmıştır. Buna göre listenin ilk başını Topluluk Kimliği kategorisi almıştır. Bu sıralamayı Eşitlikçi Kalkınma ve Sağlık+Mutluluk izlemektedir. Diğer kategorilerin ise birbirine çok yakın değerler aldığı görülmektedir.

Değerlendirme sonucunda belirlenen ağırlıklar Türkiye'de oluşturulacak özgün bir ajandanın ilk ve en önemli aşamasını oluşturmaktadır. Ancak, kapsamlı bir ajandanın geliştirilmesi için sonuç değerleri ülkenin öncelikleri ve mevcut koşulları ile uyumluluğunun analiz edilmesini gerektirmektedir.

\section{Sonuç}

Bu çalışmanın temel amacı, ortak kalkınma ve özel değerlere dayalı sürdürülebilir kalkınma projelerinin yerine komşuluk ölçeğinde sürdürülebilir planlamayı optimize etmek için GIS-AHS yönteminin potansiyelini ve EkoYer ihtiyacını araştırmaktır. İkincil amaç, hangi EkoYer ölçütlerinin mahal-

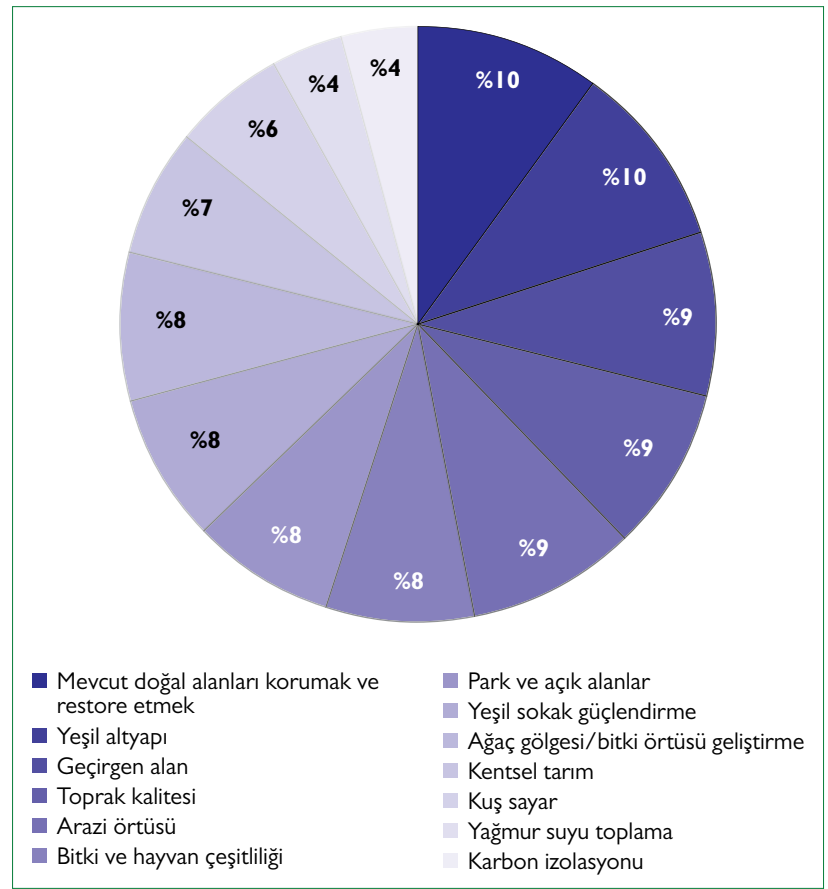

Şekil I2. Habitat+ekosistem kriter ağılıkları (\%).

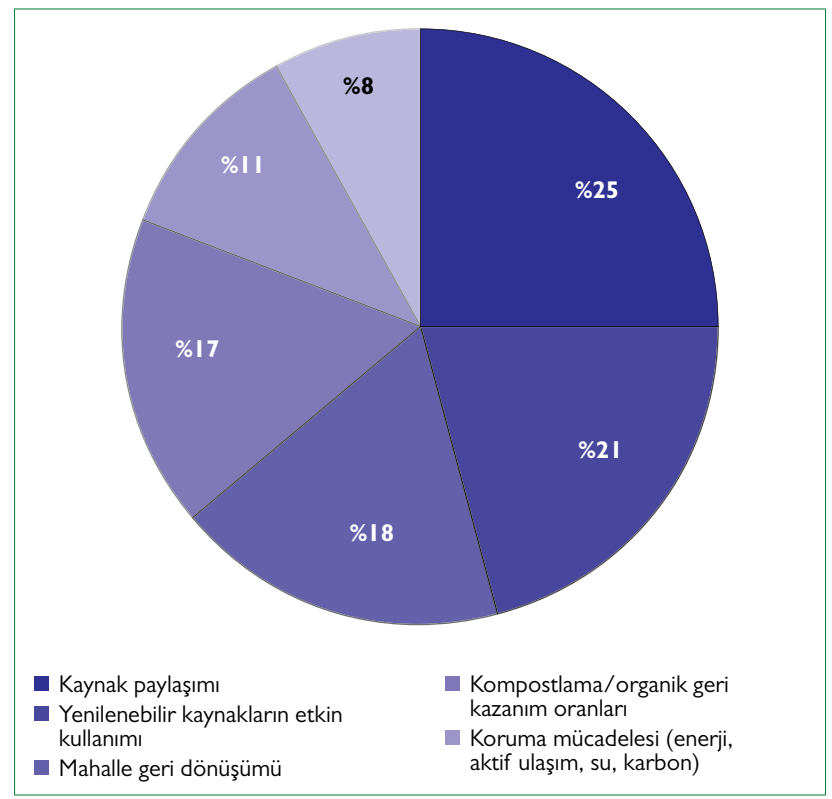

Şekil I3. Materyal yönetimi kriter ağılıkları (\%).

le ölçeğinde performansı tanımlayabildiğini belirlemek ve bu ölçütler doğrultusunda uygulanabilir bir model/rehber/ajanda hazırlamaktır.

Türkiye'de yerele özgü mahalle ölçeğinde bir EkoYer ajandasının geliştirilmesinde AHS yöntemi kullanılarak ölçütler belirlenmiştir. Bu doğrultuda mevcut yöntemlerin analizi ile elde edilen 8 kategori ve 99 kriter Analitik Hiyerarşi Sürecine göre uzmanlar tarafından önceliklere göre değerlendirilmiştir. 
Tablo 6. Önkoşul tablosu

\begin{tabular}{lc}
\hline Kategori & Kriter \\
\hline Topluluk kimliği & $\begin{array}{c}\text { Arzulanan arazi kullanımı karışımı } \\
\text { Önemli landmark, park, bina varlığı } \\
20 \text { dakikalık mahalleler }\end{array}$ \\
$\begin{array}{l}\text { Eşitlikçi kalkınma (gelişim) } \\
\text { Sağlık+mutluluk }\end{array}$ & $\begin{array}{c}\text { Kendi kendine yeten topluluk üyelerinin yüzdesi } \\
\text { Yerleşim memnuniyeti }\end{array}$ \\
$\begin{array}{l}\text { Erişim+hareketlilik } \\
\text { Su }\end{array}$ & $\begin{array}{c}20 \text { dk mahalleler (yürünebilirlik) } \\
\text { Yeşil altyapı }\end{array}$ \\
Anerji & $\begin{array}{c}\text { Akıllı yerleşim } \\
\text { Materyal yönetimi }\end{array}$ \\
Habitat+ekosistem fonksiyonu & $\begin{array}{c}\text { Yenilenebilir kaynakların etkin kullanımı paşımı } \\
\text { Yenilenebilir kaynakların etkin kullanımı }\end{array}$ \\
\hline
\end{tabular}

Tablo 5 ile ortaya çıkan öncelikler mevcut yaklaşımların ötesinde Türkiye'nin ekonomik, toplumsal ve çevresel öncelikleri ile uyumluluk göstermektedir. Öte yandan, Türkiye'de her platformda tartışılmasına karşın planlamada henüz yer almayan Toplumsal Kimlik ve Eşitlikçe Kalkınma uzman değerlendirmelerinde en üst sırada yer almaktadır. Bu çerçevede, farklı ölçeklerdeki yapılacak çalışmalarda ve bütüncül politikaların geliştirilmesinde farklı uzmanlıkların birbiri ile entegrasyonu önemli rol oynayacaktır. Değerlendirme aşamasında tanımlanacak önkoşullar, gelecekteki proje aktörlerinin bu çerçevede farkındalığını arttıran bir girdi olacaktır. AHS yöntemi ile belirlenen kategori öncelikleri, Türkiye'nin planlamadaki ulusal öncelikleri ile uyum göstermektedir.

Değerlendirilen kategori ve kriterler, uzmanların göreceli önem verdikleri önceliklere göre sıralanmışır. Sıralamada ağılık değerleri, yüzde dağııımlarına göre yeniden düzenlenerek tablolaştırıımıştır (Tablo 5). Bu değerlendirme sonuçları çerçevesinde, makale kapsamında önerilen yöntem, "topluluk kimliği, eşitlikçi kalkınma, sağlık + mutluluk” başta olmak üzere 8 kategoride toplam 13 önkoşul içermektedir (Tablo 6). Türkiye'nin planlama alanındaki ulusal hedefleri düşünülerek oluşturulan bu önkoşullar yerel ölçekte yapılacak çalışmaların başlangııını oluşturmayı amaçlamaktadır.

AHS, bir mahallenin sürdürülebilir olarak planlamasına rehberlik etmek için alternatif projelerin tanımlanması ve önceliklendirilmesi gerektiğinde kullanılacak kriterlerin seçiminde kullanışlı bir yöntem olduğunu kanıtlamıştır. 


\section{KAYNAKLAR}

Basiago, A. D. (1996). The Search For The Sustainable City In $20^{\text {th }}$ Century Urban Planning. The Environmentalist, 16, 135-155.

Beatley, T., Brower, D. J. (1993). Sustaniability Comes To Main Street. Planning. American Planning Association. 59(5):16-19

Bottero, M. (2015). A Multi-Methodological Approach For Assessing Sustainability Of Urban Projects. Management Of Environmental Quality. An International Journal, $26 \mathrm{I}(1), 138-154$.

Brody, J.S. (2009). Constructing Professional Knowledge: The Neighborhood Unit Concept In The Community Builders Handbook. (Doctor Of Philosophy), University Of Illinois At Urbana- Champaign, Urbana, Illinois.

Cash, D. W., Adger, W., Berkes, F., Garden, P., Lebel, L., Olsson, P., Pritchard, L., Young, O. (2006). Scale And Cross-Scale Dynamics: Governance And Information In A Multilevel World. Ecology And Society 11(2): 8.

Chen, H., Lin, C. (2011). Regeneration Model Of Taiwan Old Urban Centers- A Research Framework Of A Performance Evaluation System For A Livable Urban District. Journal Of Asian Architecture And Building Engineering, 163-170.

Duany, A., Roberts, P., Talen, E. (2014). A General Theory Of Urbanism Towards A System Of Assessment Based Upon Garden City Principles. Centre For Policy Studies.

Ecodistricts. (2014). The Ecodistricts Protocol: Executive Summary. Ecodistricts.

Ersoy, M. (2012). Kentsel Planlama Ansiklopetik Sözlük. Ninova Yayıncıllk

Evalina, E., Sawab, H. (2011). Garden City: The Suitability Of Its Principles As A Model To The Contemporary Planning. Nalars 10(1)1: 17-28

Fainstein, S. S. (2000). New Directions In Planning Theory. Urban Affairs Review, 35(4), 451-478.

Fishman, Robert. (1977). Urban Utopias In The Twentieth Century: Ebenezer Howard, Frank Lloyd Wright, and Le Corbusier. New York: Basic Books.

Furuseth, Owen. (1997). Neotraditional Planning: A New Strategy For Building Neighborhoods?. Elsevier. Land Use Policy. 14(3):201-213

Girard, L. F., Cerreta, M., De Toro, P. (2012). Analytic Hierarchy Process (AHP) And Geographical Information Systems (GIS): An İntegrated Spatial Assessment For Splanning Strategic Choices. International Journal Of The Analytic Hierarchy Process, 4(1).

Gonzalez, A., Donnelly, A., Jones, M., Chrysoulakis, N., Lopes, M. (2013). A Decision-Support System For The Sustainable Urban Metabolism In Europe. Environmental Impact Assessment Review, 38. 109-119.

Grant, Jill. (2006). Planning The Good Community: New Urbanism In Theory And Practice. London: Routledge.

Gutierrez, E.E. (2015). Collaborative Neighborhood-Scale Sustainability Assessment And Planning Using The Spatial Optimization For Urban Resource Conservation And Engagement (SOURCE) Tool: Applying The Analytic Hierarchy Process For Spatial Decision Support. Doctor Of Philosophy In Environmental Sciences, Oregon University, 39-47

Howard, Ebenezer. (1985). Garden Cities Of Tomorrow. Eastbourne: Attic Books.

Johnson, D. L. (2002). The Origin Of The Neighbourhood Unit. Planning Perspectives. 17(3): 227-245.

Joss, S., Cowley, R., Tomozeiu, D. (2013). Towards The 'Ubiquitous Eco-City': An Analysis Of The İnternationalisation Of Eco-City Policy And Practice. Urban Resarch \& Practice. 6(1):54-74.

Joss, S., Molella, A.P. (2013). The Eco-City As Urban Technology: Perspectives On Caofeidian International Eco-City (China). Journal Of Urban Technology. 20(1): 115-137.

Kurka, Thomas (2013). Application Of The Analytic Hierarchy Process To Evaluate The Regional Sustainability Of Bioenergy Developments. Energy. $62,393-402$.

Lavhon, Larry Lloyd. (2009). The Neighborhood Unit: Physical Design Or Physical Determinism?. Journal of Planning History. 8 (2):111-132
Lee \& Chan (2008). The Analytic Hierarchy Process (AHP) Approach For Assessment Of Urban Renewal Proposals. Social Indicators Research, 89: $155-168$

Ligmann-Zielinska, A., Church, R. L., Jankowski, P. (2008). Spatial Optimization As A Generative Technique For Sustainable Multiobjective Land-Use Allocation. International Journal Of Geographical Information Science, 22(6).

Lofti, S., Habibi, K., Koohsari, M. (2009). An Analysis Of Urban Land Development Using Multi-Criteria Decision Model And Geographical İnformation System (A Case Study Of Babosar City). American Journal Of Environmental Sciences, 5(1), 87-93.

Macleod, Gordon. (2013). New Urbanism/ Smart Growth in the Scottish Highlands: Mobile Policies and Post- politics in Local Development Planning.

Urban Studies. 50(11): 2196-2221.

Mehaffy, M. W., Porta, S., Romice, O. (2014). The "Neighborhood Unit" On Trial: A Case Study In The Impacts Of Urban Morphology. Journal Of Urbanism: International Research On Placemaking And Urban Sustainability. 8 (2):199-217

Minnery, J., Knight, J., Byrne, J., Spencer, J. (2009). Bounding Neighbourhoods: How Do Residents Do It? Planning, Practice \& Research, 24(4), 471-493.

Nasar, Jack. (2003). Does Neotraditional Development Build Community?. Journal of Planning Education and Research. 23(1):58-68

Patricios, Nicholas. (2002). The Neighborhood Concept: A Retrospective Of Physical Design And Social Interaction. The Journal Of Architectural And Planning Research, 19(1): 70-90.

Perry, C.A. (1929). The Neighborhood Unit: A Scheme Of Arrangement For The Family-Life Community Regional Plan Of New York And Its Environs New York: Arno Press.

POSI. (2011). The Ecodistrict Toolkit: Assesments. Ecodistricts Portland, Oregon, USA

POSI. (2015). Portland Ecodistrict Pilot Program Evaluation Report of Findings. Ecodistricts Portland, Oregon, USA

Poveda, C., Lipsett, M. (2013). Weighting Sustainable Development Indicators For Surface Mining Operations Using The Analytical Hierarchy Process. International Journal Of The Analytic Hierarchy Process, 5 (2).

Purdom, Charles, Benjamin. (1913). The Garden City; A Study In The Development Of The Modern Town. Printed In The Garden City At The Temple Press. London.

Register, Richard. (2006). EcoCities: Rebuilding Cities in Balance with Nature. New Society Publishers. Canada

Rohe, W. (2009). From Local To Global: One Hundred Years Of Neighborhood Planning. Journal Of The American Planning Association, 75(2), 209-230.

Saaty, T. L. (1980). The Analytic Hierarchy Process: Planning, Priority Setting, Resources Allocation. New York: Mcgraw

Schneider, F., Bonriposi, M., Graefe, O., Herweg, K., Homewood, C., Huss, M., Kauzlaric, M., Liniger, H., Rey, E., Reynard, E., Rist, S., Schädler, B., Weingartner, R. (2014). Assessing The Sustainability Of Water Governance Systems: The Sustainability Wheel. Journal of Environmental Planning and Management. 58(9): 1577-1600.

Seltzer, E. (2010). Introduction: Making EcoDistricts. Making EcoDistricts Concepts \& Methods for Advancing Sustainability in Neighborhoods. Portland, Oregon.

Sharif, A., Murayama, A. (2013a). Changes In The Traditional Urban Form And The Social Sustainability Of Contemporary Cities: A Case Study Of Iranian Cities. Habitat International, 38, 126-134.

Sharif, A., Murayama, A. (2013b). A Critical Review Of Seven Selected Neighborhood Sustainability Assessment Tools. Environmental Impact Assessment Review, 38:73-87.

Sharifi, Ayyoob. (2016). From Garden City To Eco-Urbanism: The Quest For Sustainable Neighborhood Development. Sustainable Cities and Society. 
20: $1-16$.

Silver, C. (1985). Neighborhood Planning In Historical-Perspective. Journal Of The American Planning Association, 51(2), 161-174.

Silver, C. (2006). New Urbanism and Planning History: Back to the Future. Culture, Urbanism and Planning, 179-193.

Smith, Tim. (2013). Civic Ecology: A Citizen-Driven Framework for Transforming Suburban Communities At The $50^{\text {th }}$ International Making Cities Livable Conference. Portland, Oregon.

Sohmer, R. R., Lang, R. E. (2000). Editors' Introduction - From Seaside To Southside: New Urbanism's Quest To Save The İnner City. Housing Policy Debate, 11(4), 751-760.

Talen, Emiliy. (2005). New Urbanism and American Planning- The Conflict of Cultures. Routledge. London.

Tsolakis, N., Anthopoulos, L. (2015). Eco-Cities: An Integrated System Dynamics Framework And A Concise Research Taxonomy. Elsevier. Sustainable Cities and Society. 17:1-14

Uribe, D., Geneletti, D., Del Castillo, R. F., Orsi, F. (2014). Integrating Stakeholder Preferences And GIS-Based Multicriteria Analysis To İdentify Forest Landscape Restoration Priorities. Sustainability, 6(2), 935-951.

Vernet, N., Coste, A. (2017). Garden Cities Of The 21 $1^{\text {st }}$ Century: A Sustainable Path To Suburban Reform. Urban Planning. 2 (4): 45-60

Yiğitcanlar, T. \& Ho Lee, D. (2013). Korean Ubiquitous-Eco-City: A SmartSustainable Urban Form Or A Branding Hoax? Quinsland University Of Technology. Technological Forecasting And Social Change. 89: 100-114.

Wheeler, Stephen. (2004). Planning For Sustainability: Creating Livable, Equitable, And Ecological Communities. Routledge. London. 